NBER WORKING PAPER SERIES

\title{
ONE COST OF THE CHILEAN CAPITAL CONTROLS: INCREASED FINANCIAL CONSTRAINTS FOR SMALLER TRADE FIRMS
}

\author{
Kristin J. Forbes \\ Working Paper 9777 \\ http://www.nber.org/papers/w9777

\section{NATIONAL BUREAU OF ECONOMIC RESEARCH 1050 Massachusetts Avenue Cambridge, MA 02138} \\ June 2003
}

Thanks to Jose de Gregorio, Francisco Gallego, Simon Johnson, and Jorge Roldos for extremely helpful comments and discussions. Thanks to seminar participants at Berkeley, Dartmouth, Harvard, Michigan, the Minneapolis Fed, MIT, Stanford and the World Bank for useful suggestions. Further thanks to Ken Rogoff, Carmen Reinhart and Ashoka Mody for providing generous support and encouragement at the initial stages of this project. The views expressed herein are those of the authors and not necessarily those of the National Bureau of Economic Research.

C2003 by Kristin J. Forbes. All rights reserved. Short sections of text not to exceed two paragraphs, may be quoted without explicit permission provided that full credit including (C) notice, is given to the source. 
One Cost of the Chilean Capital Controls:

Increased Financial Constraints for Smaller Traded Firms

Kristin J. Forbes

NBER Working Paper No. 9777

June 2003

JEL No. F3, F21, G1, G32, O16, O54

\begin{abstract}
There is growing support for taxes on short-term capital inflows in emerging markets, such as the encaje adopted by Chile from 1991-98. Previous empirical assessments of the encaje conclude that it may have generated some small economic benefits, such as shifting the composition of capital inflows to a longer maturity, but no significant economic costs. Managers of small and medium-sized companies in Chile, however, claim that the encaje made it substantially more difficult to obtain financing for productive investment. This paper assesses whether the Chilean capital controls increased financial constraints for different-sized, publiclytraded firms. It uses two different testing methodologies: a Tobin's q and Euler-equation framework. Results indicate that during the encaje, smaller traded firms in Chile experienced significant financial constraints and these constraints decreased as firm size increased. Both before and after the encaje, however, no group of traded firms experienced significant financial constraints, and there is no relationship between firm size and financial constraints. Although Chilean-style capital controls may also yield benefits, this cost of the encaje could be particularly important in emerging markets where smaller firms can be valuable sources of job creation and economic growth.

Kristin J. Forbes

MIT

Sloan School

Room E52-455

50 Memorial Drive

Cambridge, MA 02142

and NBER

kjforbes@mit.edu
\end{abstract}




\section{Introduction}

In the early and mid-1990's, most international economists and Washington-based policymakers supported rapid capital account liberalization for emerging markets. Many countries followed this advice. The initial results were generally positive - increased capital inflows, investment booms, and impressive growth performance. In the last decade, however, several countries with recently liberalized capital accounts experienced severe financial crises, such as Mexico, Thailand, Korea, Russia, and Argentina. These experiences, especially when combined with the recent backlash against globalization, have caused many people to question the benefits of unrestricted capital flows. ${ }^{1}$ Could controls on capital flows have prevented these crises, or at least reduced their virulence? This question recently gained prominent attention when the U.S. government insisted that free-trade agreements with Singapore and Chile include strict restrictions on their ability to use capital controls in the future.

Although there continues to be widespread disagreement on the desirability and feasibility of certain types of capital controls, such as a Tobin-style tax on currency transactions or limits on capital outflows during crises, there is increasing and fairly widespread support for market-based taxes on short-term capital inflows. For example, The Economist concluded a recent survey on global finance with the statement: “...some kinds of restriction on inflows (not outflows) of capital will make sense for many developing countries." ${ }^{2}$ The most well known example of a market-based tax on capital inflows is the encaje adopted by Chile from 1991-98. Even the IMF, formerly the bastion of capital market liberalization, has cautiously begun to support these sorts of controls. For example, Stanley Fischer, former First Deputy Managing Director of the IMF writes: "The IMF has cautiously supported the use of market-based capital inflow controls, Chilean style."3 Eduardo Aninat, a Deputy Managing Director of the IMF, recently stated: “...in some circumstances, these controls on capital inflows can play a role in reducing vulnerability created by short-term flows....The investment restrictions appear to have served Chile well..." IMF officials have even suggested that other emerging markets, such as Russia, could benefit from adopting similar capital controls in certain circumstances. ${ }^{5}$

\footnotetext{
${ }^{1}$ For an excellent study on the effects of financial globalizations, see Prasad et al. (2003).

${ }^{2}$ The Economist, “A Cruel Sea of Capital: A Survey of Global Finance.” 05/03/98, pg 24.

${ }^{3}$ Fischer (2002).

${ }^{4}$ Wall Street Journal, "Some Warm to Use of Capital Controls," by Pamela Druckerman. 10/24/02.

${ }^{5}$ For example, in an interview for the March 17, 2003 IMF Survey, John Odling-Smee, Director of the IMF's European II Department, stated that in some circumstances for Russia “...we would support some kind of market-friendly capital controls, such as the Chilean-type controls, to try to discourage speculative inflows."
} 
A series of empirical studies have supported this sea-change in attitudes by providing fairly positive or neutral assessments of the Chilean capital controls. ${ }^{6}$ Although there is some variation in the results, most studies conclude that the capital controls shifted the composition of capital inflows to a longer maturity and provided a small increase in monetary policy flexibility, but had minimal effect on other variables (such as the total volume of capital inflows or exchange rate). These studies suggest that the only costs of the controls were relatively minor, such as any deadweight loss from the government establishing and monitoring the system, or from firms attempting to evade the controls. In other words, the general interpretation of this body of empirical work is that the Chilean capital controls generated some small economic benefits, but no significant economic costs.

Managers of small and medium-sized companies in Chile, however, have a different interpretation. They claim that the capital controls made it substantially more difficult to obtain external financing. One study reports that between 1996 and 1997 (during the encaje) investment costs for smaller firms exceeded 20 percent per year, while larger firms could access international markets at a cost of only 7-8 percent. ${ }^{7}$ It is not surprising, however, that smaller firms in Chile faced a higher cost of external capital than larger firms. A large body of theoretical literature explains why asymmetric information problems, which tend to be greater in smaller and younger firms, will raise the cost of external capital relative to that for internal capital. Moreover, a large body of empirical literature documents that firms' investment decisions tend to be affected by their internal sources of funds in a range of countries, especially for smaller firms. ${ }^{8}$

There are a number of reasons, however, why the Chilean capital controls may have increased any financial constraints for smaller firms. First, many Chilean firms responded to the controls by adopting alternate forms of financing that were not subject to the tax (such as issuing ADRs or obtaining direct credit from foreign suppliers). These alternative sources of financing were not only more costly than those used before the encaje, but often unavailable to smaller firms with less established reputations. Second, and closely related, there were a number of loopholes to the capital controls, but finding and developing the mechanisms to utilize these loopholes required an up-front fixed cost. For larger firms, this fixed cost could be spread across a greater volume of financing, thereby increasing the return to finding the loopholes. As a result, larger firms were more likely than smaller firms to search for, find, and utilize these exceptions to the encaje, and therefore obtain a relatively lower cost of capital.

\footnotetext{
${ }^{6}$ These studies are discussed in more detail in Section II.

${ }^{7}$ Costs are for dollar borrowing. Cited in Edwards (1999).

${ }^{8}$ These studies are discussed in more detail in Section III.
} 
Third, banks tended to have less flexibility avoiding the encaje, since banks are more closely monitored by the central government than other firms. As a result, the cost of borrowing from banks may have risen more than the cost of borrowing from other institutions that could more easily evade the capital controls. Since smaller firms tend to be more reliant on bank loans for financing than larger firms, this additional cost would have fallen disproportionately on smaller firms, especially since they were less likely to be able to find alternate financing sources. Fourth and finally, there is some evidence that the capital controls shifted capital inflows to longer maturities. Since smaller firms have a harder time borrowing long-term than larger firms, any increase in lending maturities could have disproportionately affected the ability of small firms to obtain financing. This effect could have occurred whether the small firms received capital inflows directly, or whether they borrowed from banks (which experienced a lengthening of their maturities and attempted to match the maturities of their assets and liabilities).

Several studies of the encaje have mentioned that the capital controls might have made it relatively more difficult and expensive for smaller companies to raise financing. ${ }^{9}$ None of these studies, however, has made any attempt to assess whether these effects were significant or economically important. If the capital controls substantially increased the costs and/or constrained the ability of smaller firms to obtain capital for productive investment, this inefficient allocation of capital and resources may have reduced growth and productivity in Chile. Although the encaje may also have had important benefits, countries considering the adoption of Chilean-style capital controls should carefully evaluate this potential cost. This could be particularly important for emerging markets in which small and new firms are often important sources of job creation and economic growth. ${ }^{10}$

Therefore, this paper assesses whether the Chilean capital controls did, in fact, have this cost of increasing financial constraints for smaller, publicly-traded firms. It builds on the extensive literature on firm-financing constraints to test whether investment decisions in smaller and medium-sized traded firms are more dependent on internal finance than in large firms, and if any such differences increased during the period that the encaje was in place. Since there is a lack of agreement in this literature on the preferred testing framework, it uses the two most common methodologies: a Tobin's q framework and an Euler-equation framework. The implementation of the encaje in 1991 and its removal in 1998 provide a natural experiment by which to examine any time-series variation in financing constraints for different types of Chilean firms.

\footnotetext{
${ }^{9}$ See Gallego et al. (1999) and Edwards (1999).

${ }^{10}$ McMillan and Woodruff (2002) provide evidence on the importance of small firms and startups in promoting job creation and economic growth in the transition economies.
} 
The results indicate that investment in smaller, publicly-traded firms was significantly affected by internal finances during the period of the encaje, and that these financial constraints decreased as firm size increased. During the periods before and after the encaje, however, neither small nor large traded firms appear to have been financially constrained, and there is no significant relationship between firm size and financial constraints. These results are highly robust to an extensive series of sensitivity tests. Moreover, a series of cross-country tests does not find any evidence of similar patterns in other emerging markets during the mid-1990's, suggesting that the Chilean results are not driven by global shocks or changes in the external environment. Although this effect of the Chilean encaje is only one factor that countries should consider when evaluating whether or not to adopt controls on capital inflows, it does suggest an important cost of this policy.

The remainder of the paper is as follows. Section II provides background information on the Chilean capital controls and briefly surveys the empirical literature assessing the macroeconomic impact of these controls. Section III discusses the extensive literature testing for the presence of firm-financing constraints. It evaluates the advantages and disadvantages of different testing frameworks, and then develops two models that are used in the remainder of the paper. Section IV discusses the data set and examines trends in several variables for evidence of any impact of the encaje on different-sized, publicly-traded firms. Section V discusses several econometric issues and then estimates the base model. It also reports an extensive series of sensitivity tests and results for other emerging markets. Section VI concludes.

\section{Background on the Chilean Capital Controls}

Chile, as well as many other emerging markets, experienced a surge of capital inflows between 1988 and 1991. Largely in response, the Chilean government enacted a series of capital account restrictions in 1991. The encaje, or unremunerated reserve requirement (URR), was a key component of these restrictions. It requires that a fraction of certain types of capital inflows must be deposited at the central bank in a non-interest bearing account for a fixed term. The encaje was initially set at a rate of 20 percent and only applied to fixed-income securities and foreign loans, excluding trade credits (as long as the shipment occurred within 6 months). The tax did not initially include portfolio flows or FDI. The holding period at the central bank was initially equal to the loan's maturity, with a minimum of 90 days and maximum of 1 year. Investors were also given the option of either making the deposit at the central bank, as described above, or paying an up-front fee equivalent to the interest cost of the URR. 
The primary goal of the encaje was to moderate the appreciation of the Chilean peso in order to maintain competitive export prices. A secondary goal was to regulate short-term capital inflows, especially from banks and institutional investors, and therefore moderate the buildup of speculative short-term liabilities. A final goal was to increase the ability of the central bank to effectively use monetary policy by creating a wedge between domestic and foreign interest rates. This concern was particularly important because the government sought to reduce inflation, which was becoming increasingly difficult as any attempt to reduce demand by raising interest rates was often overwhelmed by the expansionary effect of capital inflows. Reflecting this combination of goals, the capital controls initially only covered short-term borrowing and debt, and only later expanded to cover equities and other types of portfolio flows. It is worth noting that initially a primary focus of the encaje was not to reduce Chile's vulnerability to contagion or global financial turmoil - a central motivation for other countries considering these controls.

During the 7-year period after the encaje was enacted, it was continually modified. ${ }^{11}$ These changes were aimed mainly at closing loopholes frequently discovered by investors and borrowers, although occasionally several were designed to adapt to changes in the economic environment. These modifications are summarized in Appendix A and include virtually all aspects of the encaje, such as: the fraction of the capital inflow deposited; the types of inflows covered; the currency for the deposit or fee payment; the duration of the holding period; and the restrictions on rolling-over maturing investments. In 1998, as capital flows to emerging markets dwindled, the encaje was suspended. Some of the most noteworthy changes to the encaje between 1991 and 1998, based on Appendix A, were:

- 1992: Fraction of the capital inflow deposited in the central bank was increased from $20 \%$ to $30 \%$. The minimum holding period was extended to 1 year.

- 1995: Coverage was extended to include secondary ADRs. Also, the deposit in the central bank (and calculation of the corresponding fee) had to be made in US dollars. This substantially raised the cost of the encaje. ${ }^{12}$

\footnotetext{
${ }^{11}$ During this period, there were also modifications to variety of capital account restrictions in addition to the encaje. For example, there were changes to maturity requirements, minimum size restrictions, and minimum solvency limitations for the issuance of bonds or equity abroad. There was also a continual liberalization of controls on capital outflows, such as the minimum stay period for investment abroad and ceilings on foreign asset holdings by financial institutions. See Gallego et al (1999), Simone and Sorsa (1999), and Ariyoshi et al (2000) for detailed information on this evolution of capital account restrictions over the 1990's. Section VI also discusses how these changes could affect estimates of the impact of the encaje on firm-financing constraints.

${ }^{12}$ Before 1995, investors could choose the currency of the deposit. Many chose the yen, which reduced the implicit cost of the encaje as the yen depreciated against the dollar. Simone and Sorsa (1999) estimate that changing the currency requirement raised the implicit cost of the URR by $50-100$ percent.
} 
- 1996: Coverage was extended to include "speculative investment from FDI" (defined as FDI which "does not increase productive capacity").

- 1998: Fraction of the capital inflow deposited in the central bank was decreased to $0 \%$.

During the period from 1991 to 1998 , the actual cost of the encaje depended on the maturity and/or permanence of the capital inflow, as well as the opportunity cost of the funds, with shorter-term inflows subject to a higher implicit tax (since the duration of the deposit is fixed). Table 1 reports estimates of the actual cost of the encaje for borrowings of different maturities between 1991 and 1998. It shows that although the cost fell quickly over time, it was still substantial for longer-term borrowing. For example, in 1997 the cost of the URR was $9.4 \%$ per year for 3-month borrowing and $2.4 \%$ for 1 -year borrowing. The table also shows that the changes in the encaje lead to substantial fluctuations in its cost over time. The cost increased in the first few years after the encaje was initially implemented, reaching a peak of $10.3 \%$ for 3 month borrowing in 1995. The cost fell slightly after 1995, but remained elevated until the encaje was ended in 1998.

There is some evidence, however, that although the tax rate was highest between 1994 and 1997, the actual impact on capital inflows may have declined over time. The central bank's attempts to continually close loopholes and tighten the encaje were generally effective in the short term, but over time investors and firms found new ways to evade the controls and any new restrictions. ${ }^{13}$ One of the most common strategies was to shift capital inflows to sources that were not currently subject to the encaje (such as redefining capital inflows as trade credit). Central bank data show that in 1992, the URR covered about half of total gross inflows, but in subsequent years coverage declined to 24 percent. Despite this evasion, the large revenues collected by the Chilean government suggest that the encaje still affected a substantial volume of capital inflows. Between June 1991 and September 1998, collection of the URR (including both the actual money in reserves as well as the equivalents paid in fees) increased central bank reserves by an average of $2.0 \%$ of GDP, or $40 \%$ of the average capital account surplus. ${ }^{14}$

But what was the impact of this tax? Measuring the impact of the encaje is complicated by a number of factors, such as: accurately measuring short-term inflows (since firms shifted

\footnotetext{
${ }^{13}$ See Simone and Sorsa (1999) for discussions of the effectiveness of the capital controls and evidence on their avoidance. Some authors, such as Cowan and de Gregorio (1998), argue that their "power" declined between 1995 and 1997 as evasion increased. Other authors, such as Gallego et al (1999), however, argue that their "power" increased steadily over time until the controls were removed in 1998. Valdés-Prieto and Soto (1998) also argue that the encaje was most effective after 1995.

${ }^{14}$ Gallego et al (1999).
} 
financing to trade credit, which is generally not included in short-term inflows); controlling for changes in the macro-environment (and especially the general increase in capital flows to emerging markets during this period); and controlling for simultaneous changes in other Chilean policies that could affect capital flows (such as the liberalization of capital outflows and improvements in banking system supervision and regulation). Despite these methodological challenges, a number of empirical papers have attempted to measure how the encaje impacted a series of macroeconomic variables. ${ }^{15}$ The studies use a range of modeling strategies, definitions, and econometric methodologies, and reach several general conclusions. First, there is no evidence that the encaje affected the exchange rate. Second, there is little evidence that the capital controls protected Chile from the shocks emanating from other emerging markets during the Mexican, Asian, Russian, and Brazilian crises. Third, there is some evidence that the encaje had no significant effect on the total volume of capital inflows (although this result is subject to the caveat that it is extremely difficult to construct the counterfactual of what the volume of capital inflows would have been without the encaje). Fourth, there is some evidence that the capital controls shifted the composition of capital inflows to longer maturities. Fifth and finally, there is some evidence that the encaje raised domestic interest rates by creating a wedge between domestic and foreign interest rates (although there is no agreement on whether this was a short- or long-run effect). Therefore, this series of results can be summarized as suggesting that the Chilean capital controls may have had a positive, albeit weak, impact on Chile's macroeconomy.

Despite the attention paid to the impact of the encaje on Chile's macroeconomy, there has been no analysis of how the capital controls impacted micro-level variables, such as individual firms and their cost of capital. ${ }^{16}$ The only paper that partially addresses this question, albeit indirectly, is Gallego and Loayza (2000). They provide a detailed review of the rapid growth in Chilean financial markets over the past 3 decades, and then examine how this growth affected financial development for a set of 79 publicly-listed firms between 1985 and 1995. In the section most closely related to this paper, Gallego and Loayza use a Tobin's q model and find that between 1985 and 1990, a firm's investment was not significantly affected by q, but was positively affected by cash flow and negatively by debt ratios. ${ }^{17}$ During 1991-96, however, a

\footnotetext{
${ }^{15}$ Simone and Sorsa (1999) provide an excellent survey of the empirical work on this subject, as well as a detailed discussion of the methodological and econometric problems. Four noteworthy examples of these empirical studies are Edwards (1998), Valdés-Prieto and Soto (1998), Gallego et al (1999), De Gregorio et al (2000). Edwards (2000) is one of the few studies to examine whether the capital controls reduced financial contagion.

${ }^{16}$ Work in progress by Gallego and Hernández (2002), however, is examining how the Chilean capital controls affect financial expenditures and balance sheets of Chilean firms.

${ }^{17}$ This Tobin's q model is discussed in Section III.
} 
firm's investment became more responsive to q and less to cash flow and debt ratios. This suggests that although firms were financially constrained during the late 1980's, these constraints were reduced in the first half of the 1990's. Although their paper does not explicitly discuss the impact of the encaje on financial constraints, the results suggest that during the early years of the encaje, firm financing constraints were actually lower, instead of higher, than before the capital controls were enacted. Moreover, Gallego and Loayza focus on measuring average financing constraints in Chile, and do not test for differences between small and large firms. ${ }^{18}$ Therefore, the impact of the encaje on the financing constraints of small versus large Chilean firms remains an open question.

\section{Testing Framework and Methodology}

Modigliani and Miller (1958) show that under certain conditions, including frictionless capital markets, firms should face the same cost for internal and external finance. As a result, a firm's liquidity and capital structure should not affect its investment decisions. Since this seminal article, however, there has been an extensive theoretical literature explaining why informational asymmetries and incentive problems can make external financing more expensive than internal financing, as well as an extensive empirical literature testing these propositions. ${ }^{19}$ Although results vary somewhat across studies, the majority of evidence suggests that firms predicted to have greater asymmetric information and incentive problems, and therefore be more financially constrained, tend to have a greater sensitivity of investment to fluctuations in internal funds.

Most closely related to this paper, studies of both developed countries and emerging markets have found extensive evidence that smaller firms tend to be more financially constrained than larger firms. ${ }^{20}$ Other studies, such as Love (2001) and Laeven (2002), provide cross-country evidence that firms tend to be less financially constrained in countries with more developed or liberalized financial markets. Harrison, Love and McMillan (2001) is the only study which directly considers the impact of capital controls on firm-financing constraints, although this is only a short extension of their more detailed analysis of capital flows and financing constraints. They use an Euler-equation model and find that "restrictions on payments for capital account

\footnotetext{
${ }^{18}$ Gallego and Loayza (2000) find evidence, however, that firms eligible for investment in pension funds (PFMC-grade firms) were less financially constrained than non PFMC-grade firms before 1990. Since PFMC-grade firms tend to be larger than the average Chilean firm, this suggests that smaller firms may have been more financially constrained than larger firms during this period.

${ }^{19}$ Stein (2001) and Hubbard (1998) provide excellent and thorough surveys of this theoretical and empirical literature, respectively.

${ }^{20}$ See Schiantarelli (1995) for a more detailed review of relevant studies.
} 
transactions" increase firm-financial constraints. Their measures of capital controls are based on dummy variables constructed by the IMF, however, which are highly problematic. ${ }^{21}$ In fact, these IMF dummy variables do not show an increase in Chilean capital controls when the encaje was enacted. Using a very different approach and methodology, Desai, Foley and Hines (2002) show that capital controls affect the asset allocation, financing, transfer pricing, and dividend policy of U.S. multinational affiliates. Although they do not directly test for the existence of firm-financing constraints, their results suggest that capital controls distort investment decisions.

Although this empirical literature testing for the micro-effects of capital controls and existence of financial constraints is extensive, there continues to be some disagreement on the appropriate testing framework. The earliest work on this subject estimated investment equations based on Tobin's q. This methodology, however, has been subject to rather extensive criticism, and more recent work has focused on direct estimation of Euler equations. Since each of these methodologies has different strengths and weaknesses, this paper uses a representative test from both frameworks to examine how the encaje affected financing constraints for different-sized, publicly-traded firms in Chile. As shown below, the two frameworks yield very similar estimates and results, strengthening the paper's conclusions. The remainder of this section derives the central estimating equations, placing the different methodologies within one broad framework, and discusses the advantages and disadvantages of each approach.

\section{A. The q-based Methodology}

Several different modeling strategies have been used to derive tests for firm-financing constraints based on Tobin's q. In order to facilitate comparisons with the Euler-equation model developed in Section III.B., I build on the framework developed in Gilchrist and Himmelberg (1999), Harrison et al (2001), Love (2001), and Laeven (2002). ${ }^{22}$ More specifically, assume that each firm maximizes its present value, which is the expected discounted value of dividends, subject to a capital accumulation constraint. The optimization problem is:

$$
V_{t}\left(K_{t}, \xi_{t}\right)=\max _{\left\{I_{t+s}\right\}_{s=0}^{\infty}} D_{t}+E_{t}\left[\sum_{s=1}^{\infty} \beta_{t+s-1} D_{t+s}\right]
$$

\footnotetext{
${ }^{21}$ Problems with these IMF measures of capital account restrictions have been well documented in other work. For example, see Edison et al (2002) or Kaminsky and Schmukler (2002).

${ }^{22}$ None of these papers, however, explicitly develops the q-based framework used in this subsection. Also, to simplify the analysis, I follow Love (2001) and Harrison et al. (2001) and exclude debt financing from the maximization problem. Including debt financing does not affect the first-order conditions for investment. See Gilchrist and Himmelberg (1999) or Laeven (2002) for an extension of this framework to include debt.
} 
subject to: $\quad D_{t}=\prod\left(K_{t}, \xi_{t}\right)-C\left(I_{t}, K_{t}\right)-I_{t}$

$$
K_{t+1}=(1-\delta) K_{t}+I_{t}
$$

Variables are defined as: $t$ is the current time period; $s$ represents increments to $t ; K_{t}$ is the capital stock at the start of period $t$; $\xi_{t}$ is a productivity shock; $D_{t}$ is the dividend paid to shareholders over the period $t ; E_{t}[]$ is the expectations operator conditional on information available at time $t ; \beta$ is a discount factor; $\Pi$ is the profit function (already maximized with respect to variable costs); $C$ is the adjustment cost function; $I_{t}$ is investment over the period $t$; and $\delta$ is the depreciation rate for capital.

Equation (1) can be rewritten as a Bellman equation so that the first-order condition for investment is:

$$
\left(\frac{\partial V}{\partial I}\right)_{t}=-\left(\frac{\partial C}{\partial I}\right)_{t}-1+B_{t+1} E_{t}\left[\left(\frac{\partial V}{\partial K}\right)_{t+1}\right]=0 .
$$

Next, define marginal $q_{t}$ (measured at the end of period $t$ or the start of $t+1$ ) as the increase in the firm's value (over period $t+1$ ) from one additional unit of capital (in place at the start of $t+1$ ):

$$
q_{t}=\left(\frac{\partial V}{\partial K}\right)_{t+1}
$$

In order to obtain a closed-form solution, it is necessary to specify the adjustment cost function. I make the standard assumptions of linear homogeneity in capital and investment. I also extend this standard function slightly to allow for persistence in adjustment costs, period-specific shocks, and a firm-specific level of investment that minimizes adjustment costs: ${ }^{23}$

$$
C\left(I_{t}, K_{t}\right)=\frac{1}{2 \alpha_{1}}\left[\left(\frac{I}{K}\right)_{t}-\alpha_{2}\left(\frac{I}{K}\right)_{t-1}-\alpha_{i}+\alpha_{t}\right]^{2} K_{t}
$$

\footnotetext{
${ }^{23}$ Harrison et al (2001), Laeven (2002), and Love (2001) also included a lagged term for investment and a firm-specific effect in the adjustment cost function.
} 
where $\alpha_{1}$ and $\alpha_{2}$ are constants, $\alpha_{i}$ is a fixed effect for each firm $i$, and $\alpha_{t}$ are period-specific effects. Therefore, the marginal adjustment cost of investment is:

$$
\left(\frac{\partial C}{\partial I}\right)_{t}=\frac{1}{\alpha_{1}}\left[\left(\frac{I}{K}\right)_{t}-\alpha_{2}\left(\frac{I}{K}\right)_{t-1}-\alpha_{i}+\alpha_{t}\right]
$$

Next, substitute (5) and (7) into (4), rearrange terms, and replace constants (including combinations of constants) with parameters. Finally, assume rational expectations, so that the expectations operator is replaced with realized values plus an expectational error. The expectational error $\left(\varepsilon_{i t}\right)$ is assumed to be orthogonal to any information available when the investment decision is made (at the start of the period) so that the orthogonality condition is $\mathrm{E}\left[\varepsilon_{t} \mid x_{t-s}\right]=0$ for $s \geq 1$. The resulting equation is:

$$
\left(\frac{I}{K}\right)_{i t}=\theta_{0}+\theta_{1}\left(\frac{I}{K}\right)_{i, t-1}+\theta_{2} q_{i t}+f_{i}+d_{t}+\varepsilon_{i t},
$$

where $f_{i}$ are fixed effects for each firm $i$, and $d_{t}$ are period-specific effects. According to this model, a firm's financial condition should have no impact on investment. In other words, under the assumptions of convex adjustment costs, value maximization, perfect competition, linear homogeneous technology, and capital as the only quasi-fixed input, the marginal value of Tobin's q should control for the expected future profitability of investment. To test the validity of this result, papers have added a term measuring firms' internal financial positions to equation (8) in order to evaluate whether financial constraints affect investment. For example, equation (8) is often rewritten:

$$
\left(\frac{I}{K}\right)_{i t}=\theta_{0}+\theta_{1}\left(\frac{I}{K}\right)_{i, t-1}+\theta_{2} q_{i t}+\theta_{3}\left(\frac{\text { Cash }}{K}\right)_{i t}+f_{i}+d_{t}+\varepsilon_{i t}
$$

where $\operatorname{Cash}_{i t}$ is a measure of firm $i$ 's internal financial position (such as the firm's cash stock at the start of the period or cash flow in the current or previous period). Therefore, a test for the existence of firm-financing constraints is a test of the null hypothesis that $\theta_{3}=0$ in equation $\left(8^{\prime}\right)$.

A common use of this testing framework is to divide a sample of firms based on a characteristic that is a priori expected to affect financial constraints (such as firm size or 
membership in a banking conglomerate), and then test if $\theta_{3}$ is significantly different across the groups of firms. For example, in the first of an extensive series of papers using this framework, Fazzari, Hubbard and Petersen (1988) estimate a variant of equation $\left(8^{\prime}\right)$ for firms that have either low or high dividend payout ratios. Their equivalent of $\theta_{3}$ is positive and significant for firms with lower dividend payout ratios, suggesting that this group of firms is financially constrained. ${ }^{24}$

Instead of dividing the sample of firms into two groups based on dividend policy or firm size (or any variable of interest that might affect financial constraints), a common variant of this testing framework is to interact the variable measuring financial constraints with a measure of the relevant variable of interest. For example, equation $\left(8^{\prime}\right)$ could be rewritten:

$$
\left(\frac{I}{K}\right)_{i t}=\theta_{0}+\theta_{1}\left(\frac{I}{K}\right)_{i, t-1}+\theta_{2} q_{i t}+\theta_{3}\left(\frac{\text { Cash }}{K}\right)_{i t}+\theta_{4}\left(\frac{\text { Cash }}{K} * \text { Size }\right)_{i t}+f_{i}+d_{t}+\varepsilon_{i t}
$$

Therefore, if Size is a dummy variable equal to 1 for large firms, then a test if firm-financing constraints are greater for small than large firms is a test of the null hypothesis that $\theta_{3}>\theta_{4}$.Or, if Size is a continuous measure of firm size, then a test if financial constraints exist for small firms and decrease with firm size is a test of the null hypothesis that $\theta_{3}>0$ and $\theta_{4}<0$. Although more recent papers have proposed adding a number of different control variables to equation (9) and/or testing whether different types of firms are financially constrained, this q-based methodology continues to be widely used in tests of firm's financial constraints.

This testing methodology, however, has a number of weaknesses. ${ }^{25}$ First, since it is virtually impossible to measure marginal q, most studies use average q, which will only equal marginal q under fairly restrictive assumptions. ${ }^{26}$ Second, if stock markets are inefficient, observed stock market valuations (which are a component of q) may diverge from the manager's valuation of the marginal return on capital. Third, and closely related to both of these concerns, if marginal $\mathrm{q}$ is mismeasured for any reason, then the estimated coefficients on the financial constraints' variable (or other explanatory variables) could capture shocks to investment opportunities instead of financial constraints. ${ }^{27}$ Fourth, the a priori classification of firms between those expected to be constrained or unconstrained could lead to misclassifications if firms switch

\footnotetext{
${ }^{24}$ Kaplan and Zingales (1997) critique this article and testing framework and claim to reverse the central results. Fazzari, Hubbard and Petersen (2000) respond to this critique.

${ }^{25}$ See Schiantarelli (1995) or Hubbard (1998) for a more detailed description of these issues.

${ }^{26}$ Hayashi (1982) derives these assumptions, which include: perfect competition in factor and product markets, perfect capital markets, and constant returns to scale in production technology.

${ }^{27}$ See Erickson and Whited (2000) for a discussion of problems with measurement error in $\mathrm{q}$.
} 
between the two states. Moreover, if the classifications are correlated with other variables in the equation, estimates and test statistics will be biased and inconsistent. Finally, the assumptions underlying the basic q-theory of investment, such as convex adjustment costs or value maximization, may not hold.

Despite these potential shortcomings, this q-based methodology continues to be widely used in this literature. This approach is not only intuitive, straightforward to implement, and based on strong theoretical foundations, but some authors argue that under certain assumptions, the q-based methodology may be better than more complicated testing frameworks. For these reasons, as well as to facilitate comparisons with previous work, Section V uses this q-based equation (9) to test how the encaje affected financing constraints for different sized firms in Chile. The sensitivity analysis also tests several extensions of this q-based model.

\section{B. The Euler-equation Methodology}

Due to the problems with the q-based methodology discussed above, a number of studies have instead opted to directly estimate the firm's Euler equation to test for the presence of firmfinancing constraints. This approach is based on the same basic maximization problem used to derive the q-based equations, but makes a number of different assumptions and rearranges the first-order conditions. The following derivation continues to closely follow that in Harrison et al. (2001), Love (2001), and Laeven (2002), all of which build on Gilchrist and Himmelberg (1999).

Assume that a firm faces the same optimization problem outlined in equations (1) through (3), plus the additional constraint that dividends must be non-negative:

$$
D_{t} \geq 0
$$

If $\lambda$ is the multiplier for the constraint in (10), then the first-order condition (previously equation (4)) combined with the definition in (5) is:

$$
\left(\frac{\partial V}{\partial I}\right)_{t}=-\left(1+\lambda_{t}\right)\left[\left(\frac{\partial C}{\partial I}\right)_{t}+1\right]+B_{t+1} E_{t} q_{t}=0
$$

and the envelope condition is: 


$$
\left(\frac{\partial V}{\partial K}\right)_{t}=q_{t-1}=\left(1+\lambda_{t}\right)\left(\frac{\partial D}{\partial K}\right)_{t}+(1-\delta) \beta_{t+1} E_{t} q_{t}
$$

Combining (11) and (12) to eliminate $q_{t}$ and $q_{t-1}$ yields the Euler equation: ${ }^{28}$

$$
1+\frac{\partial C\left(I_{t}, K_{t}\right)}{\partial I_{t}}=\beta_{t} E_{t}\left[\frac{1+\lambda_{t+1}}{1+\lambda_{t}}\left\{\frac{\partial \Pi\left(K_{t+1}, \xi_{t+1}\right)}{\partial K_{t+1}}+(1-\delta)\left(1+\frac{\partial C\left(I_{t+1}, K_{t+1}\right)}{\partial I_{t+1}}\right)\right\}\right] .
$$

The key variable of interest in the following analysis is $\left(1+\lambda_{t+1} / 1+\lambda_{t}\right)$, which is the relative shadow cost of external financing in period $t+1$ versus period $t$ (i.e., the measure of financial constraints). More specifically, in perfect capital markets, $\lambda_{t}=\lambda_{t+1}$. On the other hand, if the shadow cost of external funds is higher today (at $t$ ) than tomorrow (at $t+1$ ), then $\left(1+\lambda_{t+1} / 1+\lambda_{t}\right)<1$ and the firm is "financially constrained."

Next, in order to estimate equation (13), assume that the term measuring financial constraints can be written as a function of firm-specific financing constraints and the firm's cash stock at the start of the period, with the impact of the firm's cash stock allowed to vary with firm size: ${ }^{29}$

$$
\frac{1+\lambda_{t+1}}{1+\lambda_{t}}=\psi_{0 i}+\left(\psi_{1}+\psi_{2} \text { Size }_{i t}\right)\left(\frac{\text { Cash }}{K}\right)_{i t} .
$$

Also, define $M P K_{t}$ as the marginal profit of capital, net of adjustment costs and financing costs (which is the term in \{\} in equation (13)). If production follows a Cobb-Douglas function, which can have fixed costs and quasi-fixed factors of production (other than $K$ ), then $M P K_{t}$ can be expressed as:

$$
M P K_{i t}=\vartheta_{i}+\vartheta_{1, t}\left(\frac{\text { Sales }}{K}\right)_{i t}
$$

\footnotetext{
${ }^{28}$ I also follow previous literature and set $(\partial C / \partial K)_{t}=0$, since this is a second-order effect. See additional appendix to Love (2001) for a detailed explanation and evidence supporting this assumption.

${ }^{29}$ The sensitivity analysis also shows that redefining financial constraints as a function of cash flow in the current (or last period) has no significant impact on the results.
} 
where $\vartheta_{i}$ is a firm-fixed effect, $\vartheta_{l, t}$ is the ratio of capital's share in production to the markup, and Sales is total sales. ${ }^{30}$

Assume that the adjustment cost function and resulting marginal adjustment cost function are still specified by (6) and (7). Finally, since $E\left(1+\lambda_{t+1} / 1+\lambda_{t}\right) \cong 1$, it is possible to use a firstorder Taylor approximation around the means to rewrite equation (13). Continuing to assume rational expectations, and inserting the terms defined in equations (14), (15) and (7) into equation (13) yields the central estimating equation based on the Euler-equation framework:

$$
\left(\frac{I}{K}\right)_{i t}=\theta_{0}+\theta_{1}\left(\frac{I}{K}\right)_{i, t-1}+\theta_{2}\left(\frac{\text { Sales }}{K}\right)_{i t}+\theta_{3}\left(\frac{\text { Cash }}{K}\right)_{i t}+\theta_{4}\left(\frac{\text { Cash }}{K} * \text { Size }\right)_{i t}+f_{i}+d_{t}+\varepsilon_{i t}
$$

Therefore, if Size is a dummy variable equal to 1 for large firms, then a test if firmfinancing constraints are lower for large firms than for small firms is a test of the null hypothesis that $\theta_{4}<\theta_{3}$. Or, if Size is a continuous measure of firm size, then a test if financial constraints exist for small firms and decrease with firm size is a test of the null hypothesis that $\theta_{3}>0$ and $\theta_{4}<0$.

This testing strategy based on the Euler equation has several important advantages over the q-based methodology. First, it circumvents the numerous problems related to measuring marginal q. The model should therefore better control for the impact of shocks to future profitability on investment decisions, reducing any bias to the estimated coefficients on financial constraints. Second, the Euler-equation framework permits the explicit modeling of the shadow cost of financing as a function of a firm's cash stock (or other proxies for financial constraints).

Despite these important advantages, the Euler-equation methodology also has several shortcomings. First, it requires imposing a high degree of structure on the estimating equation, such as the normalization technique and form of the financial constraints. Results can be extremely sensitive to model specification, and a rejection of the "no financial constraints" hypothesis could occur for a number of reasons other than capital market imperfections. Second, tests based on the Euler-equation methodology have poor small sample properties. Third, this methodology relies on period-by-period restrictions derived from the firm's first-order conditions, so that it may not capture financial constraints that exist across periods. Fourth, the model assumes one discount rate for all firms and time periods, and although some of this effect may be

\footnotetext{
${ }^{30}$ Gilchrist and Himmelberg (1999) and Love (2002, additional appendix) provide a proof of this derivation. I have added the firm-fixed effect.
} 
captured in the firm- and period-specific effects, any residual correlation between discount rates and cash stocks or flows could bias estimates. Fifth and finally, this approach does not yield structural estimates of the key variables, so it is necessary to make assumptions about additional parameters to obtain certain coefficient estimates.

\section{Dataset}

The dataset used to estimate the two models developed in Section III is based on the Worldscope, September 2002 CD-ROM. ${ }^{31}$ I include all non-financial firms located in Chile that reported any information in the database between 1988 and 2002. ${ }^{32}$ Since the database only reports financial data for the last 10 years, I augment the data with information from the Worldscope, May 1999 CD-ROM, excluding any firms for which the time series between the two sources is inconsistent. I also exclude extreme outliers and unrealistic observations for the key variables used to estimate equations (9) and (16). Each of these steps is described in detail in Appendix B.

The Worldscope database only reports information that is publicly available, so most of the sample consists of publicly-traded companies. This has the obvious disadvantage that since many smaller firms are not publicly listed, they are underrepresented in the dataset. As a result, the analysis in this paper can only be interpreted as evidence of how the encaje affects differentsized, publicly-traded firms, and not necessarily as evidence on how the encaje affected small, private firms. Focusing mainly on publicly-listed companies, however, has two important advantages. First, disclosure requirements for public listing (which are fairly stringent in Chile, especially compared to other emerging markets) imply that the financial statistics in the dataset are more comprehensive and reliable than for most non-public firms. Second, Tobin's q is calculated based on companies' market valuations, so that this database includes the only group of firms that could be included in any analysis using the q-based approach.

Table 2 reports the number of firms in the sample by year and broad industry group. The number of firms is substantially lower at the beginning of the period - largely because Worldscope is a fairly new data set and coverage has steadily improved over time. Therefore, although firms continuously "enter" the sample, many of these entrants are not newly incorporated firms. The middle of the table reports the number of financial firms included in

\footnotetext{
${ }^{31}$ The Worldscope-Disclosure database is produced by Thomson Financial and includes detailed profiles, financial, and market information for about 32,000 companies, representing about 96 percent of the world's market capitalization. See Forbes (2000) for more detailed information on the database.

${ }^{32}$ More specifically, I exclude all financial, insurance, and real estate firms, defined as reporting a primary SIC code of 6 . Only 6 firms exit the sample due to bankruptcy, merger, purchase, or any factor that Worldscope classifies as rendering a firm "inactive".
} 
Worldscope but excluded from the dataset used for this paper, as well as the number of firms included in Worldscope but excluded from this paper due to data availability. The next set of rows reports the total number of firms listed on the Chilean stock exchange, as well as the percent of listed Chilean firms covered by Worldscope in each year of the sample. In 1988, Worldscope covered only $10 \%$ of listed firms in Chile, but by 2000 it covered $68 \%$ of listed firms. ${ }^{33}$ The bottom of the table also reports the total market capitalization of firms included in the sample, firms covered by Worldscope, and firms in the entire Chilean market. Worldscope coverage has increased from $45 \%$ of Chilean market capitalization in 1988 to $97 \%$ in 2000 . These comparisons indicate that although the Worldscope database covers most of the Chilean market when judged by size, it under-represents smaller, publicly-listed firms.

As a preliminary analysis of the impact of the encaje on firm-financing constraints in Chile, Figures 1 through 6 graph a number of relevant variables between 1988/89 and 2001 . Figure 1 begins with the average inflation-adjusted peso and foreign currency lending rates in Chile (based on IMF data), including both absolute lending rates as well as stripped lending rates. ${ }^{34}$ Peso lending rates declined fairly sharply around the time that the encaje was enacted, although they rose in the first few years of the encaje. Peso lending rates also rose in 1997-98 during the Asian and Russian crises. Foreign-currency lending rates (mainly for dollars) increased slightly in Chile during the encaje, and then fell after the encaje was removed. For example, the stripped cost of borrowing on foreign currency rose from 3.3\% in 1992 to $4.4 \%$ in 1997 , and then fell to $2.0 \%$ in 2001 . This could reflect an increased cost of borrowing resulting from the encaje, although the magnitude of the effect is fairly small and this could also be driven by other factors, such as changes in global risk aversion. Moreover, trends in aggregate interest rates do not capture any differential impact of the encaje on small versus large firms.

Therefore, Figures 2 through 6 focus on trends in key micro-level variables for smaller and large publicly-traded firms in Chile, using the dataset discussed above. Detailed variable definitions are provided in Table 3. I divide the sample into smaller and large firms, based on a cutoff of inflation-adjusted assets of 100 billion pesos (equivalent to approximately $\$ 250$ million). ${ }^{35}$ Figure 2 graphs leverage (total debt to assets) and shows that smaller public firms had

\footnotetext{
${ }^{33}$ Worldscope coverage falls slightly in 2001 due to time lags incorporating the most recent information. ${ }^{34}$ All statistics are calculated based on IMF (2002). Stripped lending rates are defined as lending rates less the interest rates on U.S. Treasury bills. Chilean lending rates are lines 22860P..zf and 22860P..fzf. US data from line 11160C..zf. Peso lending rates are adjusted for inflation using line 22864..zf.

${ }^{35}$ Inflation adjustment based on the consumer price index as reported in line 22864..zf in IMF (2002) with 1995 as the base year. The assets-based division of 100 billion pesos is chosen because it is close to the sample median of 104 billion pesos. Firms are allowed to switch between small and large in each year. The sensitivity analysis examines the impact of using different size divisions, or constraining firms to remain in
} 
leverage ratios comparable to larger firms during the later part of the encaje. Leverage ratios for large firms, however, fell during the initial years of the encaje and then increased substantially after the encaje was removed. This could indicate that large firms shifted to non-traditional financing sources during the encaje (i.e. financing that is not included in leverage ratios and was excluded from the tax), and then returned to traditional debt financing after the encaje was removed. Small firms do not show evidence of similar patterns, and actually show a decline in leverage ratios after the encaje. Figure 3 graphs the share of short-term debt in total debt and shows that smaller firms had greater shares of short-term debt than larger firms during all years (as traditionally documented in the finance literature), with the differential substantially larger before and after the encaje. Figure 4 graphs firm stock issuance as a share of beginning-of-period capital. ${ }^{36}$ Stock issuance increased dramatically for both small and large public firms during the initial stages of the encaje from 1991-94, but then declined by a comparable amount during the later half of the encaje from 1994-98. These trends are undoubtedly driven by changes in the regulations governing secondary ADRs. ${ }^{37}$ Patterns of stock issuance for small and large firms, however, are fairly similar and dominated by these aggregate trends.

Finally, Figures 5 and 6 graph investment levels and growth rates. Investment levels are fairly volatile, so that it is difficult to discern any consistent trends. At the very start and end of the sample (1988 and 2001), however, smaller firms had average investment levels greater than large firms, supporting the theory (although clearly not definitive evidence) that the encaje may have limited investment for small firms. Somewhat more convincing, investment growth in Figure 6 shows more consistent differences between the groups of firms. Investment growth for smaller firms was higher than for large firms both before 1991 and after 1998, but rarely during the period of the encaje. In fact, investment growth for smaller firms plummeted after the encaje was enacted, while simultaneously increasing for large firms. Moreover, around the time that the encaje was removed, investment growth fell for large firms and increased for smaller firms. Although none of the relationships depicted in the graphs controls for changes in investment

one category for the entire sample. Neither modification affects the key results, except that more stringent definitions for "small" firms increase estimates of financial constraints for small firms during the encaje.

${ }^{36}$ Information on stock issuance is only available for about $1 / 4$ of the sample.

${ }^{37}$ Secondary ADRs were not subject to the URR between 1991 and 1994, and thereby provided a relatively cheap and legal method of raising external financing. From 1995 until the encaje was lifted, however, secondary ADRs were subject to the same tax as other capital inflows, so that they were no longer more attractive than other sources of external financing. See Section II and Appendix A for further information. 
opportunities or other factors that could affect firm-level investment, they do suggest that the encaje may have differentially affected investment growth in small and large firms. ${ }^{38}$

\section{Estimation and Results}

This section performs more formal tests than the graphical trends reported above of how the encaje affected financing constraints for different-sized, publicly-traded firms in Chile. It begins by briefly discussing several econometric issues in estimating the models developed in Section III. Then it presents the base results, followed by an extensive series of sensitivity tests. The final part of this section repeats the base analysis for a set of additional emerging markets to test if the Chilean results are affected by any global factors.

\section{A. Econometric Issues and Estimation Methodology}

In order to estimate the q-based equation (9) and Euler-based equation (16), there are two problems with a simple OLS, fixed-effects, or random-effects estimator. ${ }^{39}$ First, many of the variables in each of the estimating equations are likely to be jointly endogenous-i.e. either simultaneously determined with the dependent variable or subject to two-way causality. For example, in the q-based equations investment and q may be jointly determined by idiosyncratic technology shocks, or higher investment could in turn increase a company's q value. Second, the presence of the lagged endogenous variable for investment will bias coefficient estimates.

To control for these issues, I use a GMM-difference estimator developed by Holtz-Eakin, Newey and Rosen (1990), Arellano and Bond (1991), and Arellano and Bover (1995). This estimator first-differences each of the variables in order to eliminate the firm-specific effects, and then uses lagged levels of the variables as instruments. ${ }^{40}$ Two critical assumptions must be

\footnotetext{
${ }^{38}$ Work in progress by the author performs a more formal analysis of some of the graphical trends discussed in this section in an effort to explain how the encaje affected financing patterns for different types of firms. The remainder of this paper, however, only attempts to document whether the encaje increased financial constraints for different types of firms, and does not explore the channels by which any such effects occurred.

${ }^{39}$ See Beck and Levine (2002) for an excellent discussion of these econometric issues and the advantages and disadvantages of different panel-GMM estimators.

${ }^{40}$ A variant of this estimator is a "GMM-system" estimator developed in Arellano and Bover (1995). This technique estimates the equation in levels using first differences as instruments, as well as the equation in differences using lagged levels as instruments. This system estimator requires not only the two assumptions in equations (17) and (18), but also the additional assumption that there is no correlation between the differenced explanatory variables and the firm-specific effects. This additional assumption, however, is rejected in this paper's dataset, as well as in Laeven (2002), which uses cross-country data to perform a similar analysis of firm-financing constraints using an Euler-equation model. Therefore, the GMM-system estimator is not valid for this paper's tests.
} 
satisfied for this estimator to be consistent and efficient. First, the explanatory variables must be predetermined by at least one period. Second, the error terms cannot be serially correlated (or at least must follow a moving average of finite order). More specifically, if $\boldsymbol{X}_{i t}{ }^{\prime}$ is the vector of explanatory variables in equations (9) or (16) and $\varepsilon_{i t}$ is the error term, then the two conditions are:

$$
\begin{aligned}
& E\left(\boldsymbol{X}_{i t}{ }^{\prime} \varepsilon_{i s}\right)=0 \text { for all } \mathrm{s}>\mathrm{t}, \text { and } \\
& E\left(\varepsilon_{i t}{ }^{\prime} \varepsilon_{i, t-s}\right)=0 \text { for all } s \geq 1 .
\end{aligned}
$$

Arellano and Bond (1991) propose two tests for the accuracy of this estimator. First, a Sargan test of over-identifying restrictions, which tests the null hypothesis of no correlation between the instruments and the residuals. Second, a test for different-order serial correlation in the residuals. If this test is unable to reject the null hypothesis of no second-order serial correlation in the differenced equation, then the level variables lagged by one period are valid instruments. If there is evidence of second-order serial correlation, but not third-order (or higher) serial correlation, then the level variables lagged by two periods are valid instruments.

One potential weakness of this GMM-difference estimator, which is discussed in Griliches and Hausman (1986), is that first differencing can exacerbate any bias resulting from measurement error. An additional potential problem is that the lagged levels of the variables can be weak instruments for the regression estimated in differences. This could not only increase the variance of the coefficient estimates, but in small samples, could also generate biased estimates. This problem is aggravated if the explanatory variables are persistent over time. Staiger and Stock (1997), however, suggest a method of testing if the lagged levels are weak instruments. They recommend regressing the first differences of each of the relevant variables on their instruments, with an F-statistic less than 5 indicating that the instruments are unreliable. ${ }^{41}$

An additional concern with this GMM estimator is that if there is no evidence of firmspecific effects, it is more efficient to estimate the equation in levels (using lagged levels as instruments) instead of in first differences. There are two methods to test if the firm-specific effects should be included in the specification. First, estimate the model in levels and test for the presence of first-order serial correlation, which would indicate the presence of unobserved firmspecific effects. Second, estimate the model in levels with firm-dummy variables and then test for the joint significance of the firm-dummy variables.

\footnotetext{
${ }^{41}$ Carpenter and Petersen (2002) use this strategy to test if lagged levels are adequate instruments for firstdifferenced equations in a similar analysis of firm-financing constraints. They suggest that an F-statistic greater than 10 indicates that the instruments are reliable.
} 
A final consideration with the GMM-difference estimator is whether to focus on firststage or second-stage robust estimates. The two-stage estimates are more efficient asymptotically, but often generate standard errors that are biased downward (especially in small samples). As a result, the two-stage estimates are less accurate for hypothesis testing, and Arellano and Bond (1991) recommend focusing on the first-stage robust estimates. ${ }^{42}$ Therefore, in the analysis below I focus on the first-stage robust estimates, although I continue to estimate each of the specifications using the two-stage robust estimates. As shown in the sensitivity analysis, using the two-stage robust estimates has no impact on the key results and conclusions, although it does tend to reduce the estimated standard errors as predicted. Therefore, focusing on the first-stage estimates is the more conservative set of hypothesis tests and should make it more difficult to find evidence of increased financing constraints for smaller firms during the encaje.

\section{B. Baseline Results for Chile}

Table 4 presents a series of initial results on the impact of the encaje on firm-financing constraints in Chile (without controlling for firm size). I focus on one-stage robust estimates that have been corrected for heteroscedasticity, using a maximum of 3 lags for each of the explanatory variables as instruments. ${ }^{43}$ Each of the explanatory variables is assumed to be predetermined instead of strictly exogenous (except the period dummy variables). Columns (1) and (2) report estimates of the Tobin's q and Euler-equation models, respectively, for the full sample of Chilean firms during the entire sample period from 1988 through 2001. Columns (3) and (4) present results for the full sample during the period before the encaje was in place (from 1988-1991); columns (5) and (6) report results for the period of the encaje (from 1992-1997); and columns (7) and (8) present results after the encaje was lifted (from 1998-2001). ${ }^{44}$ Variable definitions are the same as in Section IV and are described in detail in Table $3 .{ }^{45}$ The period dummy variables are

\footnotetext{
${ }^{42}$ Beck and Levine (2002) also make this point.

${ }^{43}$ I focus on estimates using only 3 lags instead of the full possible instrument matrix, because adding additional lags adds little explanatory power but weakens the power of the instruments. As shown in the sensitivity analysis, using fewer or additional lags has no significant impact on the results.

${ }^{44}$ The encaje was enacted in mid-1991 and removed in mid-1998. As shown in Appendix A, however, the encaje was implemented in phases and slowly phased out, so that it was substantially less stringent in 1991 and 1998. Adopting this narrower definition of the encaje period also leads to a more balanced sample distribution across the different periods, thereby facilitating estimation, especially during the earlier period when sample size is limited. Moreover, if the encaje had strong effects in 1991 or 1998, then this narrower definition should bias results against finding any impact of the encaje on financing constraints. Finally, the sensitivity analysis explores the impact of using different period definitions.

${ }^{45}$ There is an active debate on whether cash stock or cash flow is a preferred measure of a firm's liquidity. To be consistent with the most recent work in this literature (such as Harrison et al. (2001), Laeven (2002), and Love (2001)), I focus on cash stock for the base estimates. As discussed in the sensitivity analysis, the
} 
not reported, but the row labeled "Period dummies" reports the Wald statistic of a test of the null hypothesis that the period dummy variables are jointly insignificant. The lower section of the table reports test statistics for the series of tests discussed in Section V.A.

Focusing first on the coefficient estimates, the estimates for the financial constraints' variables in Table 4 fluctuate between positive and negative and are never significant at the 5 percent level. These results suggest that financing constraints were not important for the full sample of public Chilean firms during the periods before, during, and after the encaje. The other coefficient estimates generally support theoretical predictions. The coefficients on lagged investment and $q$ or Sales are usually positive, with significance fluctuating across specifications. The period dummy variables also have fluctuating significance.

The test statistics reported in Table 4 support the validity of the model specification and estimation technique. The Sargan test statistics indicate that in each case, it is impossible to reject the null hypothesis that the over-identifying restrictions are valid. ${ }^{46}$ Although the test for serial correlation suggests that second-serial correlation may be a concern for estimates based on the full period, the tests are unable to reject the null hypothesis of no second-order serial correlation for most of the sub-periods. The only exception is the Euler-based estimates for the post-encaje period, but as discussed in the sensitivity analysis, addressing this by only using the appropriate higher-order lags as instruments has no significant impact on the key results. I also estimate regressions and the corresponding F-statistics for the explanatory variables to test the validity of the instruments. In each case, the F-statistic is greater than 5, and usually greater than 10 , suggesting that the instruments are valid. ${ }^{47}$ Finally, I estimate each model in levels (instead of first differences) to test if the firm-specific effects are significant. When I exclude the firmspecific effects, tests indicate that there is first-order serial correlation for the equation in levels. When I include the firm-dummy variables, an F-test indicates that the firm-dummy variables are jointly significant. ${ }^{48}$ Both results confirm that there are unobserved firm-specific effects and therefore the model should be estimated in differences instead of levels.

Next, Table 5 repeats the same analysis as Table 4, but allows financial constraints to vary for different-sized firms, as specified in equations (9) and (16). More specifically, the top of

central results are unchanged if I replace Cash with a range of different measures of cash flow. See Love (2001) for an excellent discussion of why cash stock is a better proxy for Cash than cash flow.

${ }^{46}$ I focus on Sargan test statistics based on the two-stage estimates, since these are adjusted for heteroscedasticity. Sargan test statistics based on one-step estimates (which assume homoscedasticity in the errors) yield similar results. The null hypothesis is never rejected in either set of tests.

${ }^{47}$ For example, for the encaje period, the F-statistic from the regression of the first difference of Cash on its instruments is 19.1 for the q-based equation and 19.5 for the Euler-based equation.

${ }^{48}$ For example, for the encaje period, the F-statistic from a test of the joint significance of the firm-dummy variables is $\mathrm{F}(65,228)=68.7$ for the q-based equation and $\mathrm{F}(65,235)=222.3$ for the Euler-based equation. 
the table includes an interaction term between Cash and a size dummy variable, with Size $=1$ for large firms. ${ }^{49}$ The bottom of the table includes an interaction term between Cash and a continuous measure of firm size (Size), which is defined as $\ln$ (Assets). Therefore, the top of the table captures different financial constraints, on average, between small and large public firms, while the bottom of the table tests for any linear relationship between firm size and financial constraints.

In both the top and bottom of Table 5, coefficient estimates for the financial constraints' variables continue to be insignificant for the full period, suggesting that on average between 1988 and 2001, neither small nor large publicly-traded firms were financially constrained. Estimates from the different sub-periods, however, suggest that this result masks important differences across time. During the period when the encaje was in place, the coefficients on Cash are positive and highly significant in both parts of the table, for both the Tobin's q and Euler-equation specifications. Moreover, the coefficients on the interaction between Cash and Size (measured as either the dummy variable or continuous variable) are negative and highly significant. These results indicate that during the encaje smaller public firms were significantly more financially constrained than larger firms on average, and that as firm size increased, these financial constraints decreased.

As mentioned in Section III, however, there is extensive evidence that smaller firms tend to be more financially constrained than larger firms in a range of countries. The evidence presented in columns (5) and (6) only shows that smaller publicly-traded firms were more financially constrained than larger firms in Chile between 1992 and 1997, and does not necessarily indicate that the encaje aggravated these constraints. The results in the rest of Table 5, however, suggest that these differences in financial constraints between small and large publiclytraded firms did not exist in the periods before and after the encaje. More specifically, in columns (7) and (8) there is no evidence of financial constraints for either smaller or large firms for the period after the encaje was lifted, nor any evidence of a significant relationship between firm size and financial constraints. The coefficient estimates from the period before the encaje (in columns (3) and (4)) should be interpreted more cautiously due to the small sample sizes. With this caveat, the coefficient estimates at the top of the table suggest that before the encaje, financial constraints for large firms may have been lower than for smaller firms, but that these constraints for smaller firms were insignificant. The bottom of the table finds no significant relationship between firm size and financial constraints before the encaje. Moreover, for both the Tobin's q and Euler specifications in both parts of the table, the coefficients on Cash are significantly greater, and the

\footnotetext{
${ }^{49}$ Large firms continue to be defined as having inflation-adjusted assets greater than 100 billion pesos (the same definition as used for the graphical analysis in Section IV).
} 
coefficients on the interaction term are significantly less, during the encaje than either before or after. $^{50}$ This series of results suggests not only that smaller firms were more financially constrained than larger firms during the encaje, but also that smaller firms were more constrained during the encaje than either before or after the capital controls were in place.

Not only are the estimated financial constraints for smaller firms during the encaje significant, but also the magnitudes of the coefficient estimates suggest that this effect is economically important. Focusing first on the top of the table with the estimates based on the Size dummy variables, an increase in a smaller firm's cash-stock ratio by one standard deviation (0.426) during the encaje is correlated with an increase of about $34 \%$ to $44 \%$ in the firm's investment ratio. ${ }^{51}$ The same increase in a large firm's cash-stock ratio during the encaje is correlated with a $4 \%$ to $13 \%$ increase in the firm's investment ratio. The results at the bottom of Table 5, with Size measured by $\ln ($ Assets $)$, support these large effects. For example, focusing on the smaller estimates from the Euler-based model, for a firm with assets of 133 million pesos (the sample mean less one-third the sample standard deviation), the same one standard deviation increase in the firm's cash stock ratio would be correlated with a $26 \%$ increase in the firm's investment ratio. If the firm was twice as large (based on assets), than the same increase in the firm's cash stock ratio is correlated with a $13 \%$ increase in its investment ratio. Therefore, the estimates from both the top and bottom of Table 5 suggest that the impact of financial constraints on investment may have been economically important during the period of the encaje, and that these effects decreased rapidly as firm size increased.

The other coefficient estimates in Table 5 follow the same general patterns as reported for the full sample of firms in Table 4. The test statistics also indicate that the model continues to satisfy each of the assumptions outlined in Section V.A. The only exception is the test for secondorder serial correlation for the estimates based on the entire period, and the Euler-equation estimates for the post-encaje period. Estimating this model using only higher-order lags as instruments (in order to satisfy the assumptions for serial correlation), however, has no significant impact on the results.

\footnotetext{
${ }^{50}$ These results are based on two different testing strategies. First, I use a one-sided t-test to evaluate if the estimated coefficient is significantly greater (or less) during the encaje than the other period. Second, I estimate the model including both the encaje and the other relevant period, allowing all of the coefficients to vary across periods. Then I use a Wald test to compare the restricted model (when the coefficients on Cash and the interaction are restricted to be equal across periods) versus an unrestricted model. The key conclusion-that the constraints are significantly greater during the encaje-are identical using either test. ${ }^{51}$ For comparison, the sample mean and standard deviation for the investment ratio are $17 \%$ and $20 \%$, respectively.
} 
In order to further explore this section's central result that financial constraints are significant for smaller, traded firms and decrease with firm size during the encaje, I perform an extension to this base analysis. I divide the sample of firms into 5 approximately equally-sized groups based on firm size (as measured by total assets) and then create a new size dummy variable for each quintile. ${ }^{52}$ Then I estimate the Tobin's q and Euler-equation models, including interaction terms between Cash and each of these size-quintile dummies. Although the degrees of freedom available for estimation during the pre-encaje period are limited, this approach provides more concrete evidence on whether financial constraints decrease linearly with firm size. This approach also provides an informal test of the validity of the testing framework used in this paper and addresses some of the concerns with this methodology discussed in Section III. ${ }^{53}$

The resulting coefficient estimates are reported in Table $6 .{ }^{54}$ The estimates for the encaje period clearly suggest that as firm size increases, financial constraints decrease. In fact, for both the Tobin's q and Euler-equation models, the estimated coefficient on Cash is largest for the quintile of smallest firms, decreases by about one-third for the medium-small quintile, and then continues to decrease as firm size increases, a relationship that is particularly striking for the Tobin's q estimates. In both models the estimated coefficients on Cash are significant for the smallest two quintiles and insignificant for the largest two quintiles (with mixed results for the middle quintile). In sharp contrast to these results during the encaje, there is no pattern between financial constraints and firm size either before or after the encaje. The estimates during the preencaje period indicate that larger firms may actually have been more financially constrained than smaller firms, although it is impossible to draw any strong conclusions due to the limited sample size. More striking, however, during the post-encaje period the coefficient on Cash is not significant for any of the size quintiles, and there is no trend between size quintiles and financial constraints. These results are supported by the formal tests summarized in the columns on the far right of the table. According to both one-sided t-tests and Wald tests, the coefficient on Cash is significantly greater during the encaje period than either before or after for the smallest and medium-small firms, but not for the medium-large and large firms (with mixed results for the middle quintile).

\footnotetext{
${ }^{52}$ I divide the sample into equally-sized quintiles during the encaje period, and then use these divisions (inflation-adjusted) for each period in order to maintain consistent sizes for each quintile across periods.

${ }^{53}$ For example, if the estimated financial constraints increase with firm size based on these finer gradations, it is difficult to explain these results based on factors such as results being driven by firm characteristics other than size, or results being driven by shocks to profit opportunities that are not adequately captured in $q$ or Sales and are instead incorporated in the coefficient on Cash.

${ }_{54}$ Each specification continues to satisfy the Sargan test and serial correlation test.
} 
These results provide support for the testing framework used in this paper. Table 6 suggests that the estimates are capturing relationships between internal finances and investment for different-sized firms, and not spurious relationships caused by correlations between Cash and other firm characteristics. These results also clearly indicate that any financial constraints resulting from the encaje decreased with firm size.

\section{Sensitivity Analysis}

This section discusses an extensive analysis of the robustness of the key results reported above. Given the extensive number of tests, I only report a small subset of these results, focusing on concerns that have been raised most often in the literature. Table 7 summarizes several tests, and to conserve space and emphasize the key results, only reports coefficient estimates for the relevant financial constraints' variables for the Euler-equation model (although I continue to estimate the full model in equations (9) and (16) for each test). I focus on results when Cash is interacted with the dummy variable equal to 1 for large firms (as shown on the top of Table 5), although results when Cash is interacted with the continuous measure of firm size are equally robust. ${ }^{55}$ The base results from Section V. B. are reported in column (1), and the sensitivity tests are divided into four groups: variable definitions, model specification, estimation methodology, and sample selection.

I begin by testing if modifying the variable definitions has any significant impact on results. First, I use different measures of firm size, such as total sales or market value, and/or express each firm size variable in levels instead of logarithmic form. Second, I use different time periods to define the pre-encaje, encaje, and post-encaje periods. Column (2) only includes 199194 as the "encaje", while column (3) only includes the later period from 1995-97. ${ }^{56}$ I also use a less stringent definition of the encaje, including 1991 and 1998 (years in which the encaje was either enacted or removed). Third, instead of using cash stock at the start of the period to measure financial constraints, I use several different definitions of cash flow. For example, I use operating income, net income before preferred dividends, net income before extraordinary items, and net income (all weighted by capital stock and either for the current period or lagged by one year). Column (4) reports estimates using lagged operating income to measure Cash. Fourth, instead of weighting each of the variables (except $q$ ) by the start-of-period capital stock, I weight each of the variables by the start-of-period assets. Fifth, and finally, Gilchrist and Himmelberg (1999)

\footnotetext{
${ }^{55}$ See Forbes (2003) for results from a series of sensitivity tests when Cash is interacted with the continuous measure of firm size, using both the Tobin's q and Euler-equation models.

${ }^{56}$ See Section II for more information on the strength and coverage of the encaje in different years.
} 
suggest that the marginal profit of capital (MPK) can be defined based on operating profits instead of sales (as in equation (15)). ${ }^{57}$ I estimate the model using this alternative definition.

The next series of sensitivity tests examines the impact of altering the model specification. First, I follow a number of papers in this literature by adding different measures of leverage to equations (9) or (16). ${ }^{58}$ Column (5) of Table 7 reports results when leverage is measured by the ratio of total debt to total assets. Second, since the significance of the perioddummy variables fluctuates across specifications, I exclude the period dummies. Third, since there is no reason to expect the relationship between financial constraints and firm size to be linear, I experiment with squared and cubed interaction terms. Column (6) reports results when I include a squared interaction. In each case, the additional terms are insignificant and do not improve the equations' fit. Fourth, I follow several papers in this literature by including an accelerator term for investment. More specifically, column (7) reports results when I add a term measuring sales growth (weighted by capital). ${ }^{59}$ Fifth, I respecify the models using the growth in the investment ratio instead of the level of the investment ratio as the dependent variable. Finally, in order to test for any effect of business cycle fluctuations on financial constraints, I add a variable interacting GDP growth with $\mathrm{Cash} .{ }^{60}$ Results are reported in Column (8).

As an additional series of sensitivity tests, I examine the impact of using alternate estimation methodologies and assumptions. First, I re-estimate the model using fixed effects or random effects, both with and without the lagged term for investment. Column (9) reports results using fixed effects (without the lagged term for investment, which causes biased and inconsistent coefficient estimates under fixed effects). Second, I use different lag structures. Instead of using a maximum of 3 lags for each of the explanatory variables, I use only 1 lag, a maximum of 2, 4, or 5 lags, or as many lags as are available. I also re-estimate the model using only variables that have been lagged by two periods or more (instead of 1 period or more) in order to avoid any bias resulting from any second-order serial correlation. Third, I try using a broader set of variables as instruments. For example, I follow Love (2001) and use lagged values of the operating-profit definition of MPK and cash flow (weighted by the capital stock) as additional instruments. I also

\footnotetext{
${ }^{57}$ Gilchrist and Himmelberg (1999), as well as Love (2001), argue that the sales-based measure of MPK is better than the operating-profit based measure because the operating-profit measure assumes that there are no fixed costs or quasi-fixed factors of production (other than capital). The sales-based measure of MPK allows for fixed costs and additional quasi-fixed factors of production, although it requires an additional assumption of a Cobb-Douglas production function.

${ }^{58}$ Lang et al (1996) argue that leverage can be more important than cash flow in determining investment.

${ }^{59}$ See Gelos and Werner (2001) or Harris et al (1994) for examples of accelerator models used to estimate investment equations.

${ }^{60}$ GDP growth is calculated as log differences of annual inflation-adjusted GDP, based on lines

22899B.PXF and 22899B.PWF of IMF(2002).
} 
include sales (weighted by capital) as an instrument in the Tobin's q equation and/or leverage as an additional instrument in both equations. Column (10) reports results using the full set of additional instruments. Fourth, column (11) reports estimates of the base model using the twostage robust estimator, which tends to understate standard errors and therefore overstate coefficient significance. Finally, I alter my assumptions about whether the explanatory variables other than Cash and its interactions are constrained to remain constant across periods and size groups. ${ }^{61}$ For example, Table 8 reports results when I estimate separate equations for each period and size group, thereby allowing all coefficients to vary across periods and small/large firms. I also estimate a model constraining all of the explanatory variables other than Cash and its interactions to remain constant across periods and size groups.

As a final series of sensitivity tests, I explore the impact of sample selection and removing outliers. I remove one industry group at a time (based on Table 2), one firm at a time, and one year at a time. I also include the observations that were excluded as outliers or "unrealistic" variables (as described in Appendix B) as well as exclude the five extreme outliers for each differenced variable. Next, I exclude all "non-traditional companies", such as several sporting clubs, hospitals, and educational facilities, for which the standard accounting variables may be less informative. ${ }^{62}$ Finally, I create several more balanced panels. More specifically, I only include firms with data for every year from 1988-2001, from 1991-2000, or from 19901998. The later division is designed to maximize the number of observations but include the same set of firms in each of the time periods. These final results are reported in column (12) of Table 7.

This series of sensitivity tests reported in Tables 7 through 8 suggests that the key results reported in Section V.B are highly robust to a range of variable definitions, model specifications, estimation methodologies, and sample selection. In every single test during the encaje, the coefficient estimates on Cash are positive and significant (always at the 10 percent level and usually at the five percent level), while the coefficients on the interaction term are negative and significant. In sharp contrast, during the pre-encaje and post-encaje period the coefficients on Cash are rarely positive and significant, and the coefficients on the interaction term have fluctuating signs and significance (and are always insignificant in the post-encaje period). One of

\footnotetext{
${ }^{61}$ In the main estimates, I constrain the explanatory variables other than Cash and its interactions to be equal for small and large firms in each period, but allow them to vary across periods. I focus on this specification because it most closely follows the model developed in equations (9) and (16), which constrains the additional explanatory variables to be constant across size groups, while not imposing any additional constraints across periods. Estimates modifying these assumptions do not change the central conclusions. Moreover, the estimates in Table 5 suggest that the coefficients other than the financial constraints variables may fluctuate across periods.

${ }^{62}$ Thanks to Francisco Gallego for raising this concern.
} 
the few exceptions to these patterns is when the "encaje" period is only defined to include 199194 or 1995-97. Although the coefficient signs still follow the above patterns, the estimates in columns (2) and (3) suggest that the impact of the encaje on financing constraints for smaller firms may have been greater during the first half of this period (a result supported by the graphical evidence on investment growth in Figure 6). Finally, one-sided t-tests and Wald tests indicate that in every specification (except when the encaje is defined as lasting from 1995-97), the coefficient on Cash is significantly greater, and on the interaction coefficient is significantly less, during the encaje than in the other periods.

\section{Evidence from Other Emerging Markets}

One concern with the results reported in Tables 5-8 is that the evidence of greater financial constraints for smaller, publicly-traded Chilean firms during the mid-1990's could be driven by factors other than the encaje. For example, the series of financial crises starting in Mexico in 1994 and moving to Asia and Russia in 1997 and 1998 could have reduced investor demand for investment in smaller, less well-known firms in emerging markets. Or, the growth and development of Chilean financial markets during the 1990's could have differentially affected small and large firms (although, this effect would a priori be expected to reduce, instead of increase, relative financial constraints for small firms). Although the time-series nature of this paper's analysis makes it impossible to control for all Chilean domestic events that occurred simultaneously with the encaje, it is possible to examine changes in financial constraints in other countries to assess whether changes in the global environment are driving the central results.

To perform this analysis, I use the Worldscope database to compile a dataset identical to that described in Section IV and Appendix B for a set of emerging markets "comparable" to Chile (based on geographic location, income per capita, credit ratings, and investor assessments). Unfortunately, Worldscope coverage is extremely limited for many of these countries, especially before 1995, restricting the sample of countries that can be included in the analysis. The resulting dataset includes information for several Latin American countries (Argentina, Brazil and Mexico), several Asian countries (Korea, Malaysia, Singapore, and Taiwan), and several Eastern European countries (Czech Republic, Hungary, and Poland). Table 9 reports the sample's distribution across countries and periods.

Table 10 reports estimates of the financial constraints' coefficients in equations (9) and (16) for different groups of non-Chilean emerging markets. More specifically, it reports the coefficients for Cash and an interaction between Cash and a dummy variable equal to one for 
large firms. ${ }^{63}$ The left side of the table reports estimates for Brazil, Mexico and Singapore, and the right side of the table reports estimates for an unweighted Latin American index, Asian index, and an index including all 10 emerging markets. Although coefficient estimates vary significantly across countries/indices and periods, there is no evidence of patterns similar to those in Chile reported in Tables 5-8. More specifically, during the encaje period, there is not a single case in which the coefficient on Cash is positive and significant (at the five percent level) or the interaction term is negative and significant.

Some of the patterns reported in Table 10 (such as the significant coefficients for Singapore after 1997) could be caused by the series of crises in emerging markets during the 1990's. Interpreting each of these coefficients is beyond the scope of this paper, but nonetheless, the table suggests that the evidence of increased financial constraints for smaller, publicly-traded Chilean firms during the encaje can not be explained by any global shocks or changes in the external environment that affected comparable emerging markets over this period.

\section{Conclusions}

Managers of small and medium-sized firms in Chile argued that the encaje made it more difficult to obtain capital to fund productive investment. Despite the attention paid to the macroeconomic impact of the encaje, there was no empirical evidence supporting or refuting these arguments. The results in this paper, however, suggest that these complaints were justified. Smaller, publiclytraded Chilean firms appear to have experienced significant financial constraints during the period that the encaje was in place, but not before or after. Large Chilean firms do not appear to have experienced significant financial constraints before, during or after the encaje. Moreover, during the period of the encaje, there appears to be a strong, linear, inverse relationship between a firm's size and its degree of financial constraints.

These conclusions, however, are subject to several caveats. The sample of firms for the period before the encaje is fairly small. The dataset only includes publicly-listed firms, so that the results may not apply to a broader set of private companies. The estimates are based on linear normalizations of economic relationships that may be nonlinear. Many of the variables are imperfect measures of the underlying economic concept (such as average $\mathrm{q}$ to measure marginal $\mathrm{q}$ or sales to capture the marginal profit of capital). The GMM estimation technique may not fully

\footnotetext{
${ }^{63}$ The cutoff for large firms is based on inflation-adjusted assets and is the U.S. dollar equivalent of the cutoff used for Chile. Results are similar if the interaction term includes a continuous variable, instead of a dummy, for Size.
} 
account for joint endogeneity. Most important, firms are defined as being financially constrained if their investment is significantly affected by their cash stocks (or cash flows), after controlling for future expected profitability. Although this strategy to test for financial constraints has been widely used, there is still an active debate on the accuracy of this definition and testing strategy.

In order to address as many of these caveats as possible, this paper performs an extensive series of sensitivity tests. It examines the impact of modifying variable definitions, model specification, estimation methodology, and sample selection. It also uses two different modeling frameworks (a Tobin's q and Euler-equation methodology) to perform each of the tests. The main results are highly robust to each of these variations. The paper also repeats this analysis for a sample of additional emerging markets to see if the results are driven by changes in the global environment instead of domestic events in Chile. None of the other countries shows evidence of increased financial constraints for smaller, publicly-traded firms during the period from 1992-97, indicating that the Chilean results were not driven by external factors.

The consistency and strength of these results is particularly striking given three factors that could either bias the empirical tests against finding evidence of financial constraints for smaller Chilean firms during the encaje, or at least counteract any such impact. First, the database used for this analysis does not include the smallest firms in the Chilean economy, and even under-represents the smallest publicly-traded firms. The coefficient estimates of a highly significant, negative interaction term between Cash and a continuous measure of firm size during the encaje indicate a strong negative relationship between financial constraints and firm size. These results are supported by the estimates based on size quintiles in Table 6 . Therefore, a more representative sample including more of the smallest firms in Chile-either public or privatecould yield even greater estimates of financial constraints for "smaller" firms. ${ }^{64}$

A second factor that would be expected to reduce estimates of the impact of the encaje on smaller firms' financial constraints is the liberalization and growth of Chilean financial markets. As described in Gallego and Loayza (2000), financial market reforms led to the substantial development and deepening of Chilean financial markets in the first half of the 1990's (as compared to the later half of the 1980's). This development of domestic capital markets would be expected to not only decrease financial constraints for all firms, but to decrease financial constraints for smaller firms relatively more than for large firms (since small firms tend to be more financially constrained than larger firms in less developed financial markets). ${ }^{65}$ Although

\footnotetext{
${ }^{64}$ On the other hand, the smallest private firms may be entirely reliant on internal finances or local banks for external financing during all periods, and therefore be less affected by the encaje than small publiclytraded firms or medium-sized private firms.

${ }^{65}$ For evidence, see Love (2001) or Laeven (2002).
} 
the period dummy variables may capture any reduction in financing constraints for firms on average, this development of Chilean financial markets during the 1990's could counteract any increase in financial constraints for smaller firms relative to large firms from the encaje.

A final factor that could counteract any impact of the encaje on financial constraints for smaller firms is the contraction in lending to emerging markets that occurred during 1998 as a result of the Russian crisis and problems in Long-Term Capital Management (LTCM). Capital flows into Chile declined dramatically in 1998, and peso-borrowing rates rose. These factors would be expected to increase financial constraints for Chilean firms, especially for smaller firms. Since 1998 is included in the post-encaje period, these effects could counteract any reduction in financing constraints for smaller Chilean firms that resulted from the removal of the encaje.

Despite these three factors that would be expected to reduce estimates of any impact of the encaje on smaller firms' financial constraints, this paper still finds strong and robust evidence that the Chilean capital controls significantly increased financial constraints for smaller, publiclytraded firms, and that these constraints decreased with firm size. These results have important implications for the debate on the reform of the international financial architecture and the desirability of implementing taxes on capital inflows. Although other work suggests that the Chilean encaje might have generated some macroeconomic benefits, there has been no empirical evidence of any substantial cost to this policy. This paper suggests, however, that the encaje had the negative effect of increasing financial constraints for small and medium-sized, publicly-traded firms. This cost could be particularly important for emerging economies in which small firms are valuable engines of job creation and economic growth. As result, before countries adopt any Chilean-style tax on capital inflows, they should carefully weigh the potential benefits against the negative effects on investment and growth of smaller firms. 


\section{References}

Arellano, Manuel and Stephen R. Bond. (1991). "Some Tests of Specification for Panel Data: Monte Carlo Evidence and an Application to Employment Equations." Review of Economic Studies, 58(2, April): 277-97.

Arellano, Manuel and Olympia Bover. (1995). "Another Look at the Instrumental-Variable Estimation of Error Components Models." Journal of Econometrics, 68(1): 29-51.

Ariyoshi, Akira, Karl Habermeier, Bernard Laurens, Inci Otker-Robe, Jorge Iván CanalesKriljenko and Andrei Kirilenko. (2000). "Capital Controls: Country Experiences with Their Use and Liberalization.” IMF Occasional Paper \#190.

Beck, Thorsten and Ross Levine. (2002). "Stock Markets, Banks, and Growth: Panel Evidence." NBER Working Paper \# 9082.

Campbell, John. (1996). "Understanding Risk and Return." Journal of Political Economy, 104 (2, April): 298-345.

Carpenter, Robert E. and Bruce C. Petersen. (2002). "Is the Growth of Small Firms Constrained by Internal Finance?” Review of Economics and Statistics 84(2, May): 298-309.

Cowan, Kevin and José de Gregorio. (1998). "Exchange Rate Policies and Capital Account Management: Chile in the 1990s." In Reuven Glick, ed., Managing Capital Flows and Exchange Rates: Perspectives from the Pacific Basin. Cambridge University Press, pgs. 465-88.

De Gregorio, José, Sebastian Edwards and Rodrigo Valdés. (2000). "Controls on Capital Inflows: Do They Work?” Journal of Development Economics, 63(1, October): 59-83.

Desai, Mihir, C. Fritz Foley and James Hines. (2002). "Capital Controls, Liberalizations, and Foreign Direct Investment.” Mimeo. Harvard University and Michigan University.

Edison, Hali, Michael Klein, Luca Ricci and Torsten Sloek. (2002). "Capital Account Liberalization and Economic Performance: Survey and Synthesis.” NBER Working Paper \#9100.

Edwards, Sebastian. (2000). "Interest Rates, Contagion and Capital Controls." NBER Working Paper \#7801.

Edwards, Sebastian. (1999). "A Capital Idea? Reconsidering a Financial Quick Fix.” Foreign Affairs, 78(3): 18-22.

Edwards, Sebastian. (1998). "Capital Flows, Real Exchange Rates, and Capital Controls: Some Latin American Experiences.” NBER Working Paper \#6800.

Erickson, Timothy and Toni M. Whited. (2000). "Measurement Error and the Relationship Between Investment and Q." Journal of Political Economy, 108: 1027-57.

Fazzari, Steven M., R. Glenn Hubbard and Bruce C. Petersen. (2000). "Investment-Cash Flow Sensitivities are Useful: A Comment on Kaplan and Zingales." Quarterly Journal of Economics, 115(2, May): 695-705. 
Fazzari, Steven M., R. Glenn Hubbard and Bruce C. Peterson. (1988). "Financing Constraints and Corporate Investment." Brookings Paper on Economic Activity, 1: 141-195.

Fischer, Stanley. (2002). "Financial Crises and Reform of the International Financial System." NBER Working Paper \#9267.

Forbes, Kristin J. (2003). "One Cost of the Chilean Capital Controls: Increased Financial Constraints for Smaller Traded Firms” MIT-Sloan School Working Paper \#4273-02.

Forbes, Kristin J. (2000). "The Asian Flu and Russian Virus: Firm-Level Evidence on How Crises are Transmitted Internationally.” NBER Working Paper \#7807.

Gallego, Francisco, Leonardo Hernández, and Klaus Schmidt-Hebbel. (1999). "Capital Controls in Chile: Effective? Efficient?” Central Bank of Chile Working Paper \#59.

Gallego, Francisco, and Leonardo Hernández. (2002). "Microeconomic Effects of Capital Controls: The Chilean Experience During the 1990s." MIT mimeo.

Gallego, Francisco and Norman Loayza. (2000). "Financial Structure in Chile: Macroeconomic Developments and Microeconomic Effects." World Bank mimeo.

Gelos, R. Gaston and Alejandro Werner. (2001). "Financial Liberalization, Credit Constraints, and Collateral: Investment in the Mexican Manufacturing Sector." Journal of Development Economics, 67: 1-27.

Gilchrist, Simon and Charles P. Himmelberg. (1999). "Investment: Fundamentals and Finance." NBER Macroeconomics Annual 1998, 13: 223-62.

Gilchrist, Simon and Charles P. Himmelberg. (1995). "Evidence on the Role of Cash Flow for Investment." Journal of Monetary Economics, 36:541-72.

Griliches, Zvi and Jerry A. Hausman. (1986). "Errors in Variables in Panel Data." Journal of Econometrics 31(1, February): 93-118.

Harris, John R., Fabio Schiantarelli and Miranda G. Siregar. (1994). "The Effect of Financial Liberalization on the Capital Structure and Investment Decisions of Indonesian Manufacturing Establishments." World Bank Economic Review, 8(1): 17-47.

Harrison, Ann E., Inessa Love and Margaret S. McMillan. (2001). "Global Capital Flows and Financial Constraints." World Bank mimeo.

Hayashi, Fumio. (1982) “Tobin's Marginal q and Average q: A Neoclassical Interpretation.” Econometrica 50(1, January): 213-24.

Holtz-Eakin, Douglas, Whitney Newey and Harvey S. Rosen. (1990). "Estimating Vector Autoregressions with Panel Data." Econometrica 56 (6, November): 1371-95.

Hubbard, R. Glenn. (1998). “Capital-Market Imperfections and Investment.” Journal of Economic Literature, 36 (1,March): 193-225.

International Monetary Fund. (2002). International Financial Statistics. CD-ROM database. Sept. 
Kaminsky, Graciela and Sergio Schmukler. (2002). "Short-Run Pain, Long-Run Gain: The Effects of Financial Liberalization." World Bank mimeo.

Kaplan, Steven N. and Luigi Zingales. (1997). "Do Investment-Cash Flow Sensitivities Provide Useful Measures of Financing Constraints?” The Quarterly Journal of Economics, 112 (1, February): 169-215.

Laeven, Luc. (2002). "Financial Liberalization and Financing Constraints: Evidence from Panel Data on Emerging Economies." World Bank mimeo.

Lang, Larry, Eli Ofec and René M. Stulz. (1996). "Leverage, Investment, and Firm Growth." Journal of Financial Economics, 40: 3-29.

Love, Inessa. (2001). "Financial Development and Financing Constraints: International Evidence from the Structural Investment Model." World Bank mimeo.

McMillan, John and Christopher Woodruff. (2002). "The Central Role of Entrepreneurs in Transition Economies.” Journal of Economic Perspectives, 16(3, Summer): 153-170.

Modigliani, Franco and Merton H. Miller. (1958). "The Cost of Capital, Corporation Finance, and the Theory of Investment." American Economic Review 48(3): 261-97.

Perfect, Steven B. and Kenneth W. Wiles. (1994). “Alternative Constructions of Tobin's q: An Empirical Comparison.” Journal of Empirical Finance 1(3/4): 313-341.

Prasad, Eswar, Kenneth Rogoff, Shang-Jin Wei, and M. Ayhan Kose. (2003). "Effects of Financial Globalization on Developing Countries: Some Empirical Evidence.” International Monetary Fund Report.

Rajan, Raghuram G. and Luigi Zingales. (1998). "Financial Dependence and Growth.” American Economic Review, 88(3, June): 559-86.

Schiantarelli, Fabio. (1995). "Financial Constraints and Investment: A Critical Review of Methodological Issues and International Evidence." In Joe Peek and Eric S. Rosengreen, eds., Is Bank Lending Important for the Transmission of Monetary Policy. Federal Reserve Bank of Boston, pgs. 177-214.

Simone, Francisco Nadal De and Piritta Sorsa. (1999). "A Review of Capital Account Restrictions in Chile in the 1990s." IMF Working Paper \#99/52.

Staiger, Douglas and James Stock. (1997). "Instrumental Variables Regressions with Weak Instruments," Econometrica, 65(3, May): 557-86.

Stein, Jeremy. (2001). “Agency, Information and Corporate Investment.” In George Constantinides, Milt Harris and René Stulz, eds., Handbook of the Economics of Finance. Forthcoming.

Valdés-Prieto, Salvador and Marcelo Soto. (1998). "The Effectiveness of Capital Controls: Theory and Evidence from Chile.” Empirica 25(2): 133-64. 


\section{Appendix A: A History of the Encaje}

June 1991: The unremunerated reserve requirement (URR) was established. 20\% of capital inflows were to be deposited at the central bank in a non-interest bearing, unremunerated account denominated in the currency of the credit. The holding period was equal to the loan maturity with a minimum of 90 days and a maximum of 1 year. Borrowers could alternatively opt to pay an upfront fee (a promissory note at a discounted repurchase priced at LIBOR). The URR applied to all new foreign borrowing (by banks as well as non-financial institutions) and excluded trade credit (as long as shipment occurred within the next 6 months).

July 1991: The URR was extended to include the renewals of all borrowings (still excluding trade credits), as well as any credits linked to FDI projects.

January 1992: The URR was extended to include foreign currency deposits in commercial banks (held by domestic or foreign residents). The length of the URR for banks was also extended to equal the length of time that a deposit was in place.

May 1992: The URR was raised to $30 \%$ and extended to a minimum of 1 year (regardless of the maturity of the loan). The increase of the rate to $30 \%$ did not initially apply to direct borrowing by corporations, for which the URR stayed at $20 \%$.

August 1992: The above exception for direct borrowing by corporations was removed (so that the URR for this type of borrowing also rose to $30 \%$ ). The discount rate on the paid up-front fee was raised to LIBOR $+2.5 \%$.

October 1992: The discount rate on the paid up-front fee was raised to LIBOR $+4.0 \%$.

October 1993: The trade-credit exemption from the URR is extended to include trade credit if the merchandise is shipped within 300 days. This enlarged the trade-credit loophole.

November 1994: An announcement that starting in January 1995, the URR deposits and equivalent up-front fee can only be paid in dollars. This substantially increased the implicit cost of the URR.

July 1995: The URR was extended to include secondary ADRs (since these were no longer considered as FDI) and other inward financial instruments. Primary ADRs were still excluded from the URR (since they were viewed as capital additions).

September 1995: The period to purchase foreign exchange after selling ADRs in the domestic market was shortened to 5 days. (There was previously no regulation of foreigners selling stock holdings in the domestic market and then taking the proceeds out of the country.)

December 1995: New foreign borrowing to repay old debt (when the new loan is of equal or shorter maturity than the outstanding loan) was exempted from the URR.

May 1996: The URR was extended to cover "speculative FDI". FDI is considered nonspeculative, and therefore exempt from the URR, if it "increases productive capacity". An FDI committee decides whether FDI is speculative.

June 1996: Foreign credits can no longer be rolled over more than once a year.

December 1996: Small foreign borrowing (less than US\$200,000 per loan or less than US\$ 500,000 per year) became exempt from the URR.

\footnotetext{
${ }^{66}$ Sources: Based on Ariyoshi et al (2000, Table 1 in Appendix I), Gallego et al (1999, Annex 2), and Simone and Sorsa (1999, Table 1).
} 


\section{Appendix A: A History of the Encaje (continued)}

March 1997: The above exemption for small foreign borrowing was reduced to less than US\$ 100,000 per year (cumulative).

April 1997: The remittance of funds (principal and profits) from investments by Chileans abroad were exempt from the URR.

September 1997: Proceeds from closing positions in derivatives/options in foreign markets by Chileans were exempt from the URR.

June 1998: The URR was reduced to $10 \%$, except for short-term credit lines and foreigncurrency denominated deposits, which remained at existing rates.

August 1998: The URR was eliminated for secondary ADRs.

September 1998: The URR was reduced to $0 \%$ for all capital inflows. Foreign investors were still required to keep money in Chile for at least 1 year.

\section{Appendix B: Creation of the Data Set}

The data set used in this paper was created in several steps:

1. Compile information for all Chilean firms included on the September 2002 Worldscope CDROM. Data reported for a maximum of 10 years ending with the latest annual report.

2. Augment dataset with historical information from the May 1999 CD-ROM. Additional data is only included if the historical time series is consistent across the two sources.

3. Exclude all financial companies, defined as having a 1-digit SIC code of 6.

4. Exclude any companies that do not have information for at least 1 year for the 3 key variables necessary to estimate equation (9) or (16) - investment, cash stock, and capital stock. This leads to 1 additional exclusion (Marbella Country Club).

5. Exclude outliers and unrealistic observations for the variables used to estimate the base specifications for equations (9) or (16). More specifically, exclude individual observations where:

- $K \leq 0$ (10 observations)

- $I / K<0$ or $I / K>3$ (6 observations)

- $q<0$ or $q>10$ (1 observation)

- $C a s h / K<0$ or Cash $/ K>10$ (7 observations)

- Sales $/ K<0$ or Sales $/ K>10$ (9 observations) 


\section{Table 1}

\section{Cost of the Unremunerated Reserve Requirement (URR)}

\begin{tabular}{lccc}
\hline & \multicolumn{3}{c}{ Cost in \% per year } \\
\cline { 2 - 4 } & $\begin{array}{c}\text { 3-month } \\
\text { borrowing }\end{array}$ & $\begin{array}{c}\text { 6-month } \\
\text { borrowing }\end{array}$ & $\begin{array}{c}\text { 1-year } \\
\text { borrowing }\end{array}$ \\
\cline { 2 - 4 } 1991 & 1.5 & 1.5 & 1.5 \\
1992 (Jan-Apr) $^{2}$ & 1.1 & 1.1 & 1.1 \\
1992 (May-Dec) $^{2}$ & 7.7 & 3.9 & 1.9 \\
1993 & 6.9 & 3.4 & 1.7 \\
1994 & 9.4 & 4.7 & 2.4 \\
1995 & 10.3 & 5.1 & 2.6 \\
1996 & 9.4 & 4.7 & 2.4 \\
1997 & 9.4 & 4.7 & 2.4 \\
\hline
\end{tabular}

Notes:

(1) In each year, the approximate cost of the URR tax rate (as a percent of loanable funds) is calculated using the equation: $t=\frac{r(i *+s) T /(1+r)}{D}$, where $t$ is the implied tax rate, $r$ is the URR rate, $i *$ is the nominal interest rate for the currency in which the URR is constituted, $s$ is the premium applied to the investor when borrowing funds to cover the URR (i.e. the country risk premium plus specific credit risks for the investor), $T$ is the duration of the URR, and $D$ is the duration of the foreign investment.

(2) The division for 1992 represents changes in the duration of the URR from between 3 months and 1 year (based on the maturity of the loan) to a minimum of 1 year.

Source: From Ariyoshi et al (2000), Box 4 in Appendix I. 
Table 2: Sample Information for Chilean Firms

\begin{tabular}{|c|c|c|c|c|c|c|c|c|c|c|c|c|c|c|}
\hline Number of firms ${ }^{1}$ & 1988 & 1989 & 1990 & 1991 & 1992 & 1993 & 1994 & 1995 & 1996 & 1997 & 1998 & 1999 & 2000 & 2001 \\
\hline$\overline{\text { Food/tobacco }}$ & 5 & 5 & 5 & 9 & 10 & 11 & 12 & 15 & 16 & 18 & 23 & 30 & 27 & 26 \\
\hline Petroleum & 0 & 0 & 0 & 0 & 0 & 0 & 0 & 0 & 0 & 0 & 0 & 0 & 0 & 0 \\
\hline Consumer durables & 1 & 2 & 2 & 3 & 3 & 4 & 4 & 4 & 4 & 4 & 6 & 9 & 7 & 6 \\
\hline Textiles/trade & 1 & 1 & 1 & 1 & 1 & 1 & 2 & 2 & 2 & 4 & 9 & 14 & 14 & 14 \\
\hline Basic industry/capital goods & 3 & 3 & 5 & 10 & 10 & 12 & 13 & 13 & 14 & 15 & 18 & 32 & 29 & 24 \\
\hline Construction & 2 & 2 & 3 & 3 & 4 & 4 & 5 & 6 & 9 & 9 & 9 & 11 & 11 & 7 \\
\hline Transportation & 1 & 1 & 1 & 3 & 4 & 3 & 4 & 6 & 6 & 6 & 6 & 9 & 7 & 7 \\
\hline Utilities & 6 & 8 & 8 & 12 & 14 & 14 & 16 & 17 & 18 & 18 & 24 & 28 & 29 & 24 \\
\hline Services & 0 & 0 & 0 & 0 & 0 & 0 & 0 & 0 & 0 & 0 & 1 & 7 & 7 & 6 \\
\hline Leisure & 0 & 0 & 0 & 0 & 0 & 0 & 0 & 0 & 0 & 0 & 3 & 7 & 7 & 6 \\
\hline This paper's sample & 19 & 22 & 25 & 41 & 46 & 49 & 56 & 63 & 69 & 74 & 99 & 147 & 138 & 120 \\
\hline Financial \& excluded companies & 2 & 2 & 2 & 4 & 9 & 10 & 12 & 14 & 19 & 21 & 29 & 44 & 38 & 31 \\
\hline Total firms in Worldscope & 21 & 24 & 27 & 45 & 55 & 59 & 68 & 77 & 88 & 95 & 128 & 191 & 176 & 151 \\
\hline Listed firms in Chile $^{2}$ & 205 & 213 & 215 & 221 & 245 & 263 & 279 & 284 & 283 & 295 & 287 & 285 & 258 & 249 \\
\hline Worldscope as \% of listed firms & $10 \%$ & $11 \%$ & $13 \%$ & $20 \%$ & $22 \%$ & $22 \%$ & $24 \%$ & $27 \%$ & $31 \%$ & $32 \%$ & $45 \%$ & $67 \%$ & $68 \%$ & $61 \%$ \\
\hline \multicolumn{15}{|c|}{ Total market capitalization (in billions of pesos) ${ }^{3}$} \\
\hline This paper's sample & 0.8 & 1.5 & 2.6 & 6.7 & 8.7 & 14.2 & 19.5 & 20.5 & 19.3 & 22.1 & 17.2 & 26.8 & 26.6 & 25.8 \\
\hline Full Worldscope sample & 0.8 & 1.6 & 2.7 & 6.7 & 8.8 & 14.5 & 20.4 & 21.9 & 21.6 & 26.2 & 20.4 & 34.0 & 33.7 & 33.2 \\
\hline Total Chilean market $^{2}$ & 1.7 & 2.8 & 4.6 & 10.5 & 11.3 & 19.2 & 27.3 & 30.0 & 28.0 & 31.6 & 24.5 & 36.1 & 34.7 & 37.2 \\
\hline Worldscope as \% of total market & $45 \%$ & $56 \%$ & $58 \%$ & $64 \%$ & $78 \%$ & $76 \%$ & $75 \%$ & $73 \%$ & $77 \%$ & $83 \%$ & $83 \%$ & $94 \%$ & $97 \%$ & $89 \%$ \\
\hline
\end{tabular}

Notes: (1) SIC industry definitions are based on two-digit SIC groups defined in Campbell (1996). The only two changes are: the addition of several two-digit codes (which were not included anywhere in Campbell (1996)) to pre-specified groups; and combining basic industry with capital goods (which only had 1 company). More specifically, SIC codes for each group are: Food/tobacco (1, 2, 7, 9, 20, 21, 54); Petroleum (13, 29); Consumer durables (25, 30, 36, 37, 39, 50, $55,57)$; Textiles/trade $(22,23,31,51,53,56,59)$; Basic industry/capital goods $(8,10,12,14,24,26,28,33-35,38)$; Construction $(15-17,32,52)$; Transportation (40-42, 44, 45, 47); Utilities (46, 48, 49); Services (72, 73, 75, 76, 80-82, 87, 89); Leisure (27, 58, 70, 78, 79, 83-86, 88); and Financial (60-69).

(2) All companies listed on the Bolsa de Comercio de Santiago. Source: Emerging Stock Markets Factbook 1996 and Emerging Stock Markets Factbook 2000.

(3) Market capitalization calculated as of 12/31 in current year. 


\section{Table 3: Variable Definitions ${ }^{1}$}

\begin{tabular}{|c|c|c|}
\hline Variable & Code & Definition \\
\hline Assets (total) & & $\begin{array}{l}\text { Sum of total current assets, long-term receivables, investment in } \\
\text { unconsolidated subsidiaries, other investments, and net property, } \\
\text { plant, and equipment. Adjusted for inflation. Calculated at start- } \\
\text { of-period. Expressed in logarithmic form in regressions. }\end{array}$ \\
\hline Capital stock & $K$ & $\begin{array}{l}\text { Property, plant, and equipment (net of depreciation) at the end of } \\
\text { the period, less investment (defined below), plus depreciation } \\
\text { and amortization expenses. Calculated at start-of-period. }\end{array}$ \\
\hline Cash flow & & $\begin{array}{l}\text { Operating income, which is defined as total sales and revenues } \\
\text { less operating expenses. Weighted by } K \text { in regressions. }\end{array}$ \\
\hline Cash stock & Cash & $\begin{array}{l}\text { Cash and equivalents, which is money available for use in } \\
\text { normal operations, including short-term investments. Weighted } \\
\text { by } K \text { in regressions. Calculated at start-of-period. }\end{array}$ \\
\hline Debt (total) & & $\begin{array}{l}\text { All interest bearing and capitalized lease obligations. The book } \\
\text { value of the sum of long- and short-term debt. Calculated at } \\
\text { start-of-period. }\end{array}$ \\
\hline $\begin{array}{l}\text { Investment } \\
\text { (capital } \\
\text { expenditure) }\end{array}$ & $I$ & $\begin{array}{l}\text { Funds used to acquire fixed assets, other than those associated } \\
\text { with acquisitions. Weighted by } K \text { in regressions. }\end{array}$ \\
\hline Leverage & & $\begin{array}{l}\text { The ratio of total debt (defined above) to total assets (defined } \\
\text { above). Calculated at start-of-period. }\end{array}$ \\
\hline $\begin{array}{l}\text { Market Value (or } \\
\text { market } \\
\text { capitalization) }\end{array}$ & & $\begin{array}{l}\text { Market price at year-end multiplied by common shares } \\
\text { outstanding. For companies with more than one type of } \\
\text { common/ordinary share, market value represents the total } \\
\text { market value of the company. }\end{array}$ \\
\hline Sales (net) & Sales & $\begin{array}{l}\text { Gross sales and other operating revenues less discounts, returns } \\
\text { and allowances. Weighted by } K \text { in regressions. }\end{array}$ \\
\hline Short-term debt & & $\begin{array}{l}\text { The portion of debt payable within one year, including the } \\
\text { current portion of long-term debt and sinking fund requirements } \\
\text { of preferred stock or debentures. Calculated at start-of-period. }\end{array}$ \\
\hline Stock Issuance & & Proceeds from the sale or issuance of stock over the past year. \\
\hline Tobin's q & $q$ & $\begin{array}{l}\text { Defined as total debt (defined above) plus total market value } \\
\text { (defined above) divided by the book value of total assets } \\
\text { (defined above). Calculated at start-of-period. }\end{array}$ \\
\hline
\end{tabular}

Notes: (1) All variables calculated in Chilean pesos.

(2) Given the limited time series information available for many companies, it is impossible to use an iterative technique to estimate the replacement value of capital for the denominator of $q$. Due to the complications in calculating this replacement value, the use of the book value of total assets has become fairly common. Moreover, Perfect and Wiles (1994) show that the improvement in the measurement of $q$ from more complicated calculations is limited, especially when the regression analysis includes firm-fixed effects. 


\section{Table 4}

\section{Base Results: No Controls for Firm Size}

\begin{tabular}{|c|c|c|c|c|c|c|c|c|}
\hline & \multicolumn{2}{|c|}{ Full Period (1988-2001) } & \multicolumn{2}{|c|}{ Pre-Encaje (1988-1991) } & \multicolumn{2}{|c|}{ Encaje (1992-1997) } & \multicolumn{2}{|c|}{ Post-Encaje (1998-2001) } \\
\hline & $\begin{array}{c}\text { Tobin's q } \\
\text { (1) }\end{array}$ & $\begin{array}{c}\text { Euler } \\
(2)\end{array}$ & $\begin{array}{c}\text { Tobin's q } \\
\text { (3) }\end{array}$ & $\begin{array}{c}\text { Euler } \\
(4)\end{array}$ & $\begin{array}{c}\text { Tobin's q } \\
\text { (5) }\end{array}$ & $\begin{array}{c}\text { Euler } \\
(6)\end{array}$ & $\begin{array}{c}\text { Tobin's q } \\
\text { (7) }\end{array}$ & $\begin{array}{c}\text { Euler } \\
(8)\end{array}$ \\
\hline Investment $_{\mathrm{t}-1}$ & $\begin{array}{c}0.182 * * \\
(0.069)\end{array}$ & $\begin{array}{c}0.139 * * \\
(0.033)\end{array}$ & $\begin{array}{c}-0.030 \\
(0.136)\end{array}$ & $\begin{array}{l}-0.022 \\
(0.105)\end{array}$ & $\begin{array}{l}-0.009 \\
(0.045)\end{array}$ & $\begin{array}{c}0.148 * * \\
(0.130)\end{array}$ & $\begin{array}{c}0.264 * * \\
(0.034)\end{array}$ & $\begin{array}{l}0.144 * * \\
(0.033)\end{array}$ \\
\hline q or Sales & $\begin{array}{c}0.011 \\
(0.035)\end{array}$ & $\begin{array}{c}0.189 * * \\
(0.012)\end{array}$ & $\begin{array}{l}-0.030 \\
(0.039)\end{array}$ & $\begin{array}{c}0.099 \\
(0.084)\end{array}$ & $\begin{array}{c}0.003 \\
(0.043)\end{array}$ & $\begin{array}{c}0.374 * * \\
(0.164)\end{array}$ & $\begin{array}{c}0.180 \\
(0.177)\end{array}$ & $\begin{array}{l}0.177 * * \\
(0.011)\end{array}$ \\
\hline Cash & $\begin{array}{c}0.054 \\
(0.046) \\
\end{array}$ & $\begin{array}{c}0.022 \\
(0.025) \\
\end{array}$ & $\begin{array}{c}-0.031 \\
(0.374) \\
\end{array}$ & $\begin{array}{l}-0.330 \\
(0.231) \\
\end{array}$ & $\begin{array}{l}0.503 * \\
(0.286) \\
\end{array}$ & $\begin{array}{c}0.215 \\
(0.179) \\
\end{array}$ & $\begin{array}{c}0.024 \\
(0.023) \\
\end{array}$ & $\begin{array}{l}-0.002 \\
(0.008) \\
\end{array}$ \\
\hline Period dummies ${ }^{1}$ & $31.9 * *$ & 14.8 & $9.9 * *$ & 2.5 & 6.6 & 3.8 & 4.9 & 6.5 \\
\hline $\begin{array}{l}\text { \# observations } \\
\text { \# firms }\end{array}$ & $\begin{array}{l}562 \\
109\end{array}$ & $\begin{array}{l}594 \\
114\end{array}$ & $\begin{array}{l}30 \\
16\end{array}$ & $\begin{array}{l}38 \\
20\end{array}$ & $\begin{array}{c}252 \\
61\end{array}$ & $\begin{array}{c}262 \\
61\end{array}$ & $\begin{array}{l}280 \\
108\end{array}$ & $\begin{array}{l}294 \\
113\end{array}$ \\
\hline $\begin{array}{l}\text { Sargan test }{ }^{2} \\
\text { Serial correlation }^{3}\end{array}$ & $\begin{array}{r}73.6 \\
-1.9 * \\
\end{array}$ & $\begin{array}{r}75.2 \\
-2.4 * * \\
\end{array}$ & $\begin{array}{l}10.1 \\
-1.1\end{array}$ & $\begin{array}{c}14.2 \\
0.5 \\
\end{array}$ & $\begin{array}{l}54.0 \\
-1.5 \\
\end{array}$ & $\begin{array}{l}58.1 \\
-1.4 \\
\end{array}$ & $\begin{array}{l}47.5 \\
-1.0 \\
\end{array}$ & $\begin{array}{r}47.2 \\
-2.4 * * \\
\end{array}$ \\
\hline
\end{tabular}

Notes: * is significant at the 10 percent level and ** is significant at the 5 percent level. "Tobin's q" are the q-based estimates in equation (9). "Euler" are the Euler-equation based estimates in equation (16). Neither equation, however, includes the interaction between Cash and Size.

(1) Period dummies is the Wald statistic of a test of the null hypothesis that the period dummy variables are jointly insignificant.

(2) Sargan test is the $\chi^{2}$ statistic of a test of the null hypothesis that the over-identifying restrictions are valid. Statistics are based on the two-step estimator, so that the test is adjusted for heteroscedasticity.

(3) Serial correlation is the Z-statistic from a test of the null hypothesis of no second-order serial correlation in the residuals. 
Table 5: Base Results: Cash Stock Interacted with Firm Size

\begin{tabular}{|c|c|c|c|c|c|c|c|c|}
\hline \multirow{2}{*}{$\begin{array}{l}\text { Interaction with } \\
\text { Large Firm } \\
\text { Dummy }\end{array}$} & \multicolumn{2}{|c|}{ Full Period (1988-2001) } & \multicolumn{2}{|c|}{ Pre-Encaje (1988-1991) } & \multicolumn{2}{|c|}{ Encaje Period (1992-97) } & \multicolumn{2}{|c|}{ Post-Encaje (1998-2001) } \\
\hline & $\begin{array}{l}\text { Tobin's q } \\
\text { (1) }\end{array}$ & $\begin{array}{c}\text { Euler } \\
\text { (2) }\end{array}$ & $\begin{array}{c}\text { Tobin's q } \\
\text { (3) }\end{array}$ & $\begin{array}{c}\text { Euler } \\
(4)\end{array}$ & $\begin{array}{c}\text { Tobin's q } \\
\text { (5) }\end{array}$ & $\begin{array}{c}\text { Euler } \\
(6)\end{array}$ & $\begin{array}{c}\text { Tobin's q } \\
\text { (7) }\end{array}$ & $\begin{array}{c}\text { Euler } \\
(8)\end{array}$ \\
\hline$\overline{\text { Investment }_{\mathrm{t}-1}}$ & $\begin{array}{c}0.150 * * \\
(0.073)\end{array}$ & $\begin{array}{c}0.135^{* *} * \\
(0.033)\end{array}$ & $\begin{array}{c}-0.165^{*} \\
(0.100)\end{array}$ & $\begin{array}{l}-0.088 \\
(0.041)\end{array}$ & $\begin{array}{l}-0.065 \\
(0.064)\end{array}$ & $\begin{array}{c}0.128 \\
(0.148)\end{array}$ & $\begin{array}{c}0.238^{* *} \\
(0.032)\end{array}$ & $\begin{array}{c}0.145 * * \\
(0.032)\end{array}$ \\
\hline q or Sales & $\begin{array}{c}0.026 \\
(0.039)\end{array}$ & $\begin{array}{c}0.180^{* *} \\
(0.015)\end{array}$ & $\begin{array}{c}-0.006 \\
(0.036)\end{array}$ & $\begin{array}{c}0.050 \\
(0.092)\end{array}$ & $\begin{array}{c}0.017 \\
(0.060)\end{array}$ & $\begin{array}{c}0.343 * * \\
(0.124)\end{array}$ & $\begin{array}{c}0.235 \\
(0.201)\end{array}$ & $\begin{array}{c}0.170 * * \\
(0.018)\end{array}$ \\
\hline Cash & $\begin{array}{c}0.045 \\
(0.049)\end{array}$ & $\begin{array}{c}0.027 \\
(0.034)\end{array}$ & $\begin{array}{c}0.074 \\
(0.287)\end{array}$ & $\begin{array}{c}-0.149 \\
(0.179)\end{array}$ & $\begin{array}{l}1.039 * * \\
(0.501)\end{array}$ & $\begin{array}{c}0.797 * * \\
(0.300)\end{array}$ & $\begin{array}{c}0.010 \\
(0.008)\end{array}$ & $\begin{array}{c}-0.008 \\
(0.015)\end{array}$ \\
\hline Cash*Size Dummy & $\begin{array}{c}-0.009 \\
(0.063)\end{array}$ & $\begin{array}{c}-0.022 \\
(0.046)\end{array}$ & $\begin{array}{c}-0.348 * \\
(0.188)\end{array}$ & $\begin{array}{c}-0.357 * * \\
(0.087)\end{array}$ & $\begin{array}{c}-0.732 * \\
(0.424)\end{array}$ & $\begin{array}{c}-0.713^{* *} \\
(0.282)\end{array}$ & $\begin{array}{c}0.023 \\
(0.021)\end{array}$ & $\begin{array}{c}0.023 \\
(0.038)\end{array}$ \\
\hline Period dummies $^{1}$ & $31.2 * *$ & 14.1 & $38.6^{* *}$ & 5.4 & 7.3 & 3.4 & 3.9 & 7.1 \\
\hline $\begin{array}{l}\text { \# observations } \\
\text { \# firms } \\
\text { Sargan test }{ }^{2} \\
\text { Serial correlation }^{3}\end{array}$ & $\begin{array}{c}562 \\
109 \\
77.7 \\
-2.0^{*} \\
\end{array}$ & $\begin{array}{r}594 \\
114 \\
75.2 \\
-2.4 * * \\
\end{array}$ & $\begin{array}{c}30 \\
16 \\
10.9 \\
-1.1 \\
\end{array}$ & $\begin{array}{c}38 \\
20 \\
12.4 \\
0.4 \\
\end{array}$ & $\begin{array}{c}252 \\
61 \\
51.1 \\
-0.9 \\
\end{array}$ & $\begin{array}{c}262 \\
61 \\
50.6 \\
-0.7 \\
\end{array}$ & $\begin{array}{l}280 \\
108 \\
65.0 \\
-1.0 \\
\end{array}$ & $\begin{array}{r}294 \\
113 \\
66.2 \\
-2.1 * * \\
\end{array}$ \\
\hline \multicolumn{9}{|c|}{ Interaction with $\ln ($ Assets) } \\
\hline Investment $_{\mathrm{t}-1}$ & $\begin{array}{c}0.156^{* *} \\
(0.073)\end{array}$ & $\begin{array}{c}0.135 * * \\
(0.035)\end{array}$ & $\begin{array}{c}0.028 \\
(0.104)\end{array}$ & $\begin{array}{c}-0.010 \\
(0.088)\end{array}$ & $\begin{array}{c}-0.027 \\
(0.073)\end{array}$ & $\begin{array}{c}0.120 \\
(0.127)\end{array}$ & $\begin{array}{c}0.245 * * \\
(0.033)\end{array}$ & $\begin{array}{c}0.141 * * \\
(0.034)\end{array}$ \\
\hline q or Sales & $\begin{array}{c}0.025 \\
(0.040)\end{array}$ & $\begin{array}{c}0.180 * * \\
(0.016)\end{array}$ & $\begin{array}{c}-0.034 \\
(0.037)\end{array}$ & $\begin{array}{c}0.089 \\
(0.086)\end{array}$ & $\begin{array}{c}0.034 \\
(0.060)\end{array}$ & $\begin{array}{c}0.285^{* *} \\
(0.115)\end{array}$ & $\begin{array}{c}0.171 \\
(0.133)\end{array}$ & $\begin{array}{c}0.169 * * \\
(0.018)\end{array}$ \\
\hline Cash & $\begin{array}{c}0.033 \\
(0.246)\end{array}$ & $\begin{array}{c}-0.021 \\
(0.184)\end{array}$ & $\begin{array}{l}-2.738 \\
(3.870)\end{array}$ & $\begin{array}{c}0.841 \\
(3.429)\end{array}$ & $\begin{array}{l}7.852 * * \\
(3.736)\end{array}$ & $\begin{array}{l}5.851 * * \\
(2.780)\end{array}$ & $\begin{array}{c}-0.083 \\
(0.094)\end{array}$ & $\begin{array}{c}-0.098 \\
(0.154)\end{array}$ \\
\hline Cash $^{*}$ Size & $\begin{array}{c}0.002 \\
(0.020)\end{array}$ & $\begin{array}{c}0.004 \\
(0.016) \\
\end{array}$ & $\begin{array}{c}0.227 \\
(0.350)\end{array}$ & $\begin{array}{l}-0.095 \\
(0.303)\end{array}$ & $\begin{array}{c}-0.588 * * \\
(0.286)\end{array}$ & $\begin{array}{c}-0.444 * * \\
(0.217)\end{array}$ & $\begin{array}{c}0.009 \\
(0.009)\end{array}$ & $\begin{array}{c}0.008 \\
(0.014)\end{array}$ \\
\hline Period dummies $^{1}$ & $29.4^{* *}$ & 13.9 & $9.4 * *$ & 2.7 & 3.2 & 5.3 & $5.3 * *$ & 7.1 \\
\hline \# observations & 562 & 594 & 30 & 38 & 252 & 262 & 280 & 294 \\
\hline \# firms & 109 & 114 & 16 & 20 & 61 & 61 & 108 & 113 \\
\hline Sargan test ${ }^{2}$ & 74.1 & 78.5 & 9.7 & 14.6 & 54.6 & 54.4 & 67.7 & 62.9 \\
\hline Serial correlation $^{3}$ & $-1.9 *$ & $-2.4 * *$ & -0.9 & 0.4 & -1.0 & -0.8 & -1.0 & $-2.1 * *$ \\
\hline
\end{tabular}

Notes: Top of table includes an interaction term between Cash and a size dummy variable equal to 1 for large firms. Large firms defined as having inflation-adjusted assets greater than 100 billion pesos. Bottom of table includes an interaction between Cash and $\ln$ (Assets).* is significant at the 10 percent level and ** is significant at the 5 percent level. "Tobin's q" are the q-based estimates in equation (9). "Euler" are the Euler-equation based estimates in equation (16). See notes to table 4 for numbered footnotes. 
Table 6: Financial Constraints for Quintiles of Different-Sized Firms

\begin{tabular}{|c|c|c|c|c|c|c|c|c|c|c|}
\hline & \multirow{2}{*}{\multicolumn{2}{|c|}{$\begin{array}{l}\text { Pre-encaje }^{1} \\
(1988-1993)\end{array}$}} & \multirow{2}{*}{\multicolumn{2}{|c|}{$\begin{array}{c}\text { Encaje } \\
(1992-1997)\end{array}$}} & \multirow{2}{*}{\multicolumn{2}{|c|}{$\begin{array}{l}\text { Post-encaje } \\
(1998-2001)\end{array}$}} & \multicolumn{4}{|c|}{$\begin{array}{l}\text { Is Coefficient Significantly } \\
\text { Greater During Encaje than }{ }^{2} \text { : }\end{array}$} \\
\hline & & & & & & & Pre & ncaje & Post & encaje \\
\hline$I_{t-1}$ & $\begin{array}{c}\mathbf{q} \\
0.087 \\
(0.125)\end{array}$ & $\begin{array}{c}\text { Euler } \\
0.151 \\
(0.105)\end{array}$ & $\begin{array}{c}\mathbf{q} \\
-0.066 \\
(0.057)\end{array}$ & $\begin{array}{c}\text { Euler } \\
0.090 \\
(0.138)\end{array}$ & $\begin{array}{c}\mathbf{q} \\
0.170 * * \\
(0.034)\end{array}$ & $\begin{array}{c}\text { Euler } \\
0.118^{* *} \\
(0.048)\end{array}$ & $\mathbf{q}$ & Euler & $q$ & Euler \\
\hline q or Sales & $\begin{array}{c}0.013 \\
(0.029)\end{array}$ & $\begin{array}{c}0.186 * * \\
(0.053)\end{array}$ & $\begin{array}{c}0.023 \\
(0.044)\end{array}$ & $\begin{array}{c}0.304 * * \\
(0.124)\end{array}$ & $\begin{array}{c}0.238 \\
(0.192)\end{array}$ & $\begin{array}{c}0.163 * * \\
(0.022)\end{array}$ & & & & \\
\hline $\begin{array}{l}\text { Smallest Dummy } \\
\text { * Cash }\end{array}$ & -- & $\begin{array}{l}-1.399 \\
(0.978)\end{array}$ & $\begin{array}{c}0.942 * * \\
(0.231)\end{array}$ & $\begin{array}{c}0.959 * * \\
(0.216)\end{array}$ & $\begin{array}{c}0.010 \\
(0.007)\end{array}$ & $\begin{array}{l}-0.016 \\
(0.024)\end{array}$ & -- & $\mathrm{Y}^{* *}$ & $\mathrm{Y}^{* *}$ & $\mathrm{Y}^{* *}$ \\
\hline $\begin{array}{l}\text { Medium-Small } \\
\text { Dummy * Cash }\end{array}$ & $\begin{array}{c}0.207 \\
(0.236)\end{array}$ & $\begin{array}{c}0.143 \\
(0.378)\end{array}$ & $\begin{array}{l}0.685^{*} \\
(0.419)\end{array}$ & $\begin{array}{c}0.549 * * \\
(0.280)\end{array}$ & $\begin{array}{c}0.094 \\
(0.100)\end{array}$ & $\begin{array}{c}0.011 \\
(0.133)\end{array}$ & $\mathrm{Y}^{* *}$ & $\mathrm{Y}^{* *}$ & $\mathrm{Y}^{* *}$ & $\mathrm{Y}^{* *}$ \\
\hline $\begin{array}{l}\text { Medium Dummy } \\
\text { * Cash }\end{array}$ & $\begin{array}{c}-0.461 \\
(0.311)\end{array}$ & $\begin{array}{c}-0.726^{* *} \\
(0.138)\end{array}$ & $\begin{array}{c}0.345 * * \\
(0.093)\end{array}$ & $\begin{array}{c}0.001 \\
(0.122)\end{array}$ & $\begin{array}{c}0.029 \\
(0.029)\end{array}$ & $\begin{array}{c}0.007 \\
(0.026)\end{array}$ & $\mathrm{Y}^{* *}$ & $\mathrm{Y}^{* *}$ & $\mathrm{Y}^{* *}$ & $\mathrm{~N}$ \\
\hline $\begin{array}{l}\text { Medium-Large } \\
\text { Dummy * Cash }\end{array}$ & $\begin{array}{l}1.239^{*} \\
(0.631)\end{array}$ & $\begin{array}{c}1.009 \\
(0.720)\end{array}$ & $\begin{array}{c}0.179 \\
(0.150)\end{array}$ & $\begin{array}{l}-0.130 \\
(0.167)\end{array}$ & $\begin{array}{c}0.520 \\
(0.518)\end{array}$ & $\begin{array}{c}0.164 \\
(0.191)\end{array}$ & $\mathrm{N}$ & $\mathrm{N}$ & $\mathrm{N}$ & $\mathrm{N}$ \\
\hline $\begin{array}{l}\text { Largest Dummy } \\
\text { * Cash }\end{array}$ & $\begin{array}{c}2.002 * * \\
(0.689)\end{array}$ & $\begin{array}{l}1.429 * * \\
(0.534)\end{array}$ & $\begin{array}{c}0.103 \\
(0.149)\end{array}$ & $\begin{array}{c}0.093 \\
(0.099) \\
\end{array}$ & $\begin{array}{c}0.120 \\
(0.122)\end{array}$ & $\begin{array}{c}0.043 \\
(0.083)\end{array}$ & $\mathrm{N}$ & $\mathrm{N}$ & $\mathrm{N}$ & $\mathrm{N}$ \\
\hline $\begin{array}{l}\text { \# observations } \\
\text { \# firms }\end{array}$ & $\begin{array}{l}47 \\
18\end{array}$ & $\begin{array}{l}58 \\
21\end{array}$ & $\begin{array}{c}252 \\
61\end{array}$ & $\begin{array}{c}262 \\
61 \\
\end{array}$ & $\begin{array}{l}280 \\
108\end{array}$ & $\begin{array}{l}294 \\
113\end{array}$ & & & & \\
\hline
\end{tabular}

Notes: Standard errors in parentheses. * is significant at the $10 \%$ level and ** is significant at the 5\% level. "q" represents Tobin's q-based equation (9) and "Euler" is Euler-based equation (16). Cash is interacted with dummy variables for firm size quintiles. Firm size is measured by total assets in billions of inflation-adjusted pesos. Quintile divisions are based on sample distribution during the encaje, and then divisions are held constant across periods. Regression includes period dummy variables (not reported).

(1) Pre-encaje period extended through 1993 in order to have sufficient degrees of freedom for meaningful estimation.

(2) Summary result of both a one-sided t-test and a Wald test if the estimated coefficient on the cash interaction is significantly greater during the encaje than the other period. "Y" denotes yes (according to both tests) and "N" denotes no. Stars continue to indicate degree of significance. 
Table 7: Sensitivity Analysis: Euler-based Equations with Size Dummies

\begin{tabular}{|c|c|c|c|c|c|c|c|c|c|c|c|c|}
\hline Pre-encaje & $\begin{array}{c}\text { Base }^{1} \\
(1) \\
\end{array}$ & $\begin{array}{c}\text { Encaje: } \\
\text { 1991-94 }^{2} \\
(2)\end{array}$ & $\begin{array}{c}\text { Encaje: } \\
\text { 1995-97 }^{3} \\
(3)\end{array}$ & $\begin{array}{c}\text { Cash } \\
\text { flow }^{4} \\
(4) \\
\end{array}$ & $\begin{array}{c}\text { Add } \\
\text { leverage } \\
(5) \\
\end{array}$ & $\begin{array}{c}\text { Squared } \\
\text { interact. }^{6} \\
(6) \\
\end{array}$ & $\begin{array}{c}\text { Add Accel- } \\
\text { erator }^{7} \\
(7)\end{array}$ & $\begin{array}{c}\text { Add Bus. } \\
\text { Cycle }^{8} \\
(8)\end{array}$ & $\begin{array}{c}\text { Fixed } \\
\text { effects } \\
(9) \\
\end{array}$ & $\begin{array}{c}\text { Add Instru- } \\
\text { ments }^{10} \\
(10)\end{array}$ & $\begin{array}{c}\text { Two- } \\
\text { Stage }{ }^{11} \\
(11) \\
\end{array}$ & $\begin{array}{c}\text { Balanced } \\
\text { Panel }^{12} \\
(12) \\
\end{array}$ \\
\hline Cash & $\begin{array}{l}-0.149 \\
(0.179)\end{array}$ & $\begin{array}{l}0.728^{* *} \\
(0.270)\end{array}$ & $\begin{array}{l}0.565^{*} \\
(0.321)\end{array}$ & $\begin{array}{c}0.381 \\
(0.242)\end{array}$ & $\begin{array}{l}-0.055 \\
(0.181)\end{array}$ & $\begin{array}{c}0.077 \\
(0.154)\end{array}$ & $\begin{array}{l}-0.146 \\
(0.179)\end{array}$ & $\begin{array}{l}-0.260 \\
(0.328)\end{array}$ & $\begin{array}{l}-0.132 \\
(0.208)\end{array}$ & $\begin{array}{c}-0.134 \\
(0.186)\end{array}$ & $\begin{array}{c}-0.348^{* *} \\
(0.174)\end{array}$ & $\begin{array}{l}-0.149 \\
(0.179)\end{array}$ \\
\hline Interaction & $\begin{array}{c}-0.357 * * \\
(0.087)\end{array}$ & $\begin{array}{c}-0.352 * * \\
(0.122)\end{array}$ & $\begin{array}{c}-0.757 * * \\
(0.225)\end{array}$ & $\begin{array}{l}-0.072 \\
(0.064)\end{array}$ & $\begin{array}{c}-0.307 * * \\
(0.147)\end{array}$ & $\begin{array}{c}0.517 \\
(0.315)\end{array}$ & $\begin{array}{c}-0.382 * * \\
(0.089)\end{array}$ & $\begin{array}{c}-0.300 * * \\
(0.110)\end{array}$ & $\begin{array}{l}-0.090 \\
(0.175)\end{array}$ & $\begin{array}{c}-0.287 * * \\
(0.117)\end{array}$ & $\begin{array}{c}-0.372 * * \\
(0.050)\end{array}$ & $\begin{array}{c}-0.357^{* *} \\
(0.087)\end{array}$ \\
\hline $\begin{array}{l}\text { Encaje } \\
\text { Cash }\end{array}$ & $\begin{array}{c}0.797^{* *} \\
(0.300)\end{array}$ & $\begin{array}{c}0.969^{* *} \\
(0.441)\end{array}$ & $\begin{array}{l}0.350^{*} \\
(0.192)\end{array}$ & $\begin{array}{r}0.642 * * \\
(0.317)\end{array}$ & $\begin{array}{l}0.808^{* *} \\
(0.299)\end{array}$ & $\begin{array}{c}0.804^{* *} \\
(0.295)\end{array}$ & $\begin{array}{c}0.740^{* *} \\
(0.286)\end{array}$ & $\begin{array}{l}0.528^{*} \\
(0.307)\end{array}$ & $\begin{array}{c}0.316^{* *} \\
(0.093)\end{array}$ & $\begin{array}{c}0.828 * * \\
(0.287)\end{array}$ & $\begin{array}{c}0.808^{* *} \\
(0.009)\end{array}$ & $\begin{array}{c}0.944 * * \\
(0.354)\end{array}$ \\
\hline Interaction & $\begin{array}{c}-0.713 * * \\
(0.282)\end{array}$ & $\begin{array}{c}-1.172 * * \\
(0.404)\end{array}$ & $\begin{array}{c}-0.271 * * \\
(0.134)\end{array}$ & $\begin{array}{c}-0.621 * * \\
(0.317)\end{array}$ & $\begin{array}{c}-0.707 * * \\
(0.279)\end{array}$ & $\begin{array}{c}-0.723 * * \\
(0.277)\end{array}$ & $\begin{array}{c}-0.717 * * \\
(0.260)\end{array}$ & $\begin{array}{c}-0.757 * * \\
(0.281)\end{array}$ & $\begin{array}{l}-0.170^{*} \\
(0.096)\end{array}$ & $\begin{array}{c}-0.730^{* *} \\
(0.273)\end{array}$ & $\begin{array}{c}-0.725^{* *} \\
(0.007)\end{array}$ & $\begin{array}{c}-0.776^{* *} \\
(0.343)\end{array}$ \\
\hline $\begin{array}{l}\text { Post-Encaje } \\
\text { Cash }\end{array}$ & $\begin{array}{l}-0.008 \\
(0.015)\end{array}$ & $\begin{array}{l}-0.003 \\
(0.013)\end{array}$ & $\begin{array}{l}-0.008 \\
(0.015)\end{array}$ & $\begin{array}{c}0.003 \\
(0.005)\end{array}$ & $\begin{array}{l}-0.011 \\
(0.017)\end{array}$ & $\begin{array}{l}-0.007 \\
(0.015)\end{array}$ & $\begin{array}{l}-0.203 \\
(0.162)\end{array}$ & $\begin{array}{l}-0.058 \\
(0.052)\end{array}$ & $\begin{array}{l}-0.095 \\
(0.058)\end{array}$ & $\begin{array}{l}-0.013 \\
(0.020)\end{array}$ & $\begin{array}{c}0.002 \\
(0.008)\end{array}$ & $\begin{array}{l}-0.011 \\
(0.055)\end{array}$ \\
\hline Interaction & $\begin{array}{c}0.023 \\
(0.038)\end{array}$ & $\begin{array}{c}0.000 \\
(0.026)\end{array}$ & $\begin{array}{c}0.023 \\
(0.038)\end{array}$ & $\begin{array}{l}-0.006 \\
(0.010)\end{array}$ & $\begin{array}{c}0.052 \\
(0.054)\end{array}$ & $\begin{array}{c}0.130 \\
(0.112)\end{array}$ & $\begin{array}{c}0.209 \\
(0.154)\end{array}$ & $\begin{array}{c}0.082 \\
(0.078)\end{array}$ & $\begin{array}{c}0.102 \\
(0.062)\end{array}$ & $\begin{array}{c}0.009 \\
(0.025)\end{array}$ & $\begin{array}{c}0.010 \\
(0.009)\end{array}$ & $\begin{array}{c}0.012 \\
(0.056)\end{array}$ \\
\hline
\end{tabular}

Notes "Euler" estimates from equation (16). The interaction term is the coefficient on the interaction between Cash and Size, with Size equal to 1 for large firms. Standard errors are in parentheses. Throughout the table, * denotes significance at the 10 percent level and ** denotes significance at the 5 percent level.
(1) Base estimates, with full results reported at the top of Table 5
(2) Redefine encaje as period from 1991-94. Years from 1995-97 included in the post-encaje period. 1991 no longer included in pre-encaje period.
(3) Redefine encaje period to focus on the later period from 1995-97. Years from 1991-94 included in the pre-encaje period.
(4) Financial constraints redefined as lagged cash flow instead of cash stock. Cash flow defined in Table 3.
(5) Add an additional variable controlling for leverage to each of the specifications. Leverage defined in Table 3.
(6) Include a squared interaction between Cash and Size. Coefficient estimates on the squared term are not reported but are highly insignificant.
(7) Include accelerator variables, measured by sales growth (over the start-of-period capital stock).
(8) To control for business cycle effects, add a control variable that is an interaction between GDP growth and Cash.
(9) Model estimated using fixed effects (with no instruments). Lagged term for investment is excluded.
(10) Model estimated with additional instruments: cash flow (weighted by capital stock), leverage, and the operating profit definition of MPK.
(11) Model estimated using the two-stage robust estimator.
(12) Sample restricted to a balanced panel including only companies with data for every year from 1990 through 1998 (so the sample of firms is constant across periods).


Table 8

Sensitivity Analysis: All Coefficients Allowed to Vary by Period and Size Group

\begin{tabular}{|c|c|c|c|c|c|c|}
\hline \multirow[b]{2}{*}{$\underline{\text { Small Firms }}$} & \multicolumn{2}{|c|}{ Pre-encaje $^{1}$} & \multicolumn{2}{|c|}{ Encaje } & \multicolumn{2}{|c|}{ Post-encaje } \\
\hline & $q$ & Euler & $q$ & Euler & $q$ & Euler \\
\hline$\overline{I_{t-1}}$ & $\begin{array}{c}-0.659 * * \\
(0.185)\end{array}$ & $\begin{array}{c}-0.440 * * \\
(0.206)\end{array}$ & $\begin{array}{c}-0.175 \\
(0.106)\end{array}$ & $\begin{array}{c}0.127 \\
(0.236)\end{array}$ & $\begin{array}{c}-0.041 \\
(0.042)\end{array}$ & $\begin{array}{c}0.015 \\
(0.051)\end{array}$ \\
\hline qor sales & $\begin{array}{c}0.001 \\
(0.029)\end{array}$ & $\begin{array}{c}0.252 * * \\
(0.083)\end{array}$ & $\begin{array}{c}0.078 \\
(0.093)\end{array}$ & $\begin{array}{l}0.335 * \\
(0.173)\end{array}$ & $\begin{array}{c}0.105 \\
(0.082)\end{array}$ & $\begin{array}{c}0.053 * * \\
(0.020)\end{array}$ \\
\hline Cash & $\begin{array}{c}0.559 \\
(0.489) \\
\end{array}$ & $\begin{array}{c}0.112 \\
(0.332)\end{array}$ & $\begin{array}{c}0.734 * * \\
(0.324)\end{array}$ & $\begin{array}{c}0.735 * * \\
(0.333)\end{array}$ & $\begin{array}{c}0.013 \\
(0.010)\end{array}$ & $\begin{array}{c}0.007 \\
(0.007)\end{array}$ \\
\hline$\# o b s$ & 18 & 25 & 93 & 102 & 106 & 119 \\
\hline \multicolumn{7}{|l|}{ Large Firms } \\
\hline$\overline{I_{t-1}}$ & $\begin{array}{l}-0.131 \\
(0.085)\end{array}$ & $\begin{array}{l}-0.010 \\
(0.045)\end{array}$ & $\begin{array}{c}-0.041 \\
(0.137)\end{array}$ & $\begin{array}{c}0.038 \\
(0.111)\end{array}$ & $\begin{array}{c}0.201 * * \\
(0.015)\end{array}$ & $\begin{array}{c}0.183 * * \\
(0.008)\end{array}$ \\
\hline q or sales & $\begin{array}{c}0.060 \\
(0.060)\end{array}$ & $\begin{array}{l}0.207 * \\
(0.113)\end{array}$ & $\begin{array}{c}-0.008 \\
(0.042)\end{array}$ & $\begin{array}{c}0.248 * * \\
(0.080)\end{array}$ & $\begin{array}{c}0.389 \\
(0.432)\end{array}$ & $\begin{array}{c}0.186 * * \\
(0.003)\end{array}$ \\
\hline Cash & $\begin{array}{c}0.530 * * \\
(0.120)\end{array}$ & $\begin{array}{l}0.335 * \\
(0.173) \\
\end{array}$ & $\begin{array}{c}0.193 * * \\
(0.079)\end{array}$ & $\begin{array}{c}0.024 \\
(0.068) \\
\end{array}$ & $\begin{array}{c}0.059 \\
(0.057) \\
\end{array}$ & $\begin{array}{c}0.008 \\
(0.029) \\
\end{array}$ \\
\hline$\#$ obs & 62 & 68 & 159 & 160 & 174 & 175 \\
\hline
\end{tabular}

Notes: Standard errors in parentheses. * and ** are significant at the $10 \%$ and $5 \%$ levels, respectively. "q" is equation (9) and "Euler" is equation (16).

Period dummy variables are included but not reported. Estimate model separately for large and small firms in each period, excluding the Cash*Size interaction. (1) Pre-encaje period extended through 1993 in order to have sufficient degrees of freedom for estimation. 
Table 9

Number of Firms in Non-Chilean Emerging Market Sample

\begin{tabular}{|c|c|c|c|c|c|c|c|c|c|c|c|c|c|c|}
\hline & 1988 & 1989 & 1990 & 1991 & 1992 & 1993 & 1994 & 1995 & 1996 & 1997 & 1998 & 1999 & 2000 & 2001 \\
\hline Argentina & 0 & 0 & 3 & 2 & 4 & 7 & 13 & 15 & 18 & 22 & 24 & 25 & 26 & 27 \\
\hline Brazil & 0 & 0 & 0 & 1 & 8 & 57 & 59 & 72 & 92 & 83 & 96 & 108 & 177 & 158 \\
\hline Mexico & 1 & 9 & 10 & 14 & 21 & 35 & 41 & 44 & 48 & 52 & 60 & 70 & 75 & 38 \\
\hline Latin America index ${ }^{l}$ & 1 & 9 & 13 & 17 & 33 & 99 & 113 & 131 & 158 & 157 & 180 & 203 & 278 & 223 \\
\hline Korea & 0 & 2 & 4 & 2 & 4 & 1 & 5 & 20 & 15 & 13 & 13 & 46 & 117 & 129 \\
\hline Malaysia & 0 & 5 & 28 & 32 & 65 & 92 & 96 & 117 & 175 & 215 & 243 & 226 & 232 & 257 \\
\hline Singapore & 0 & 9 & 24 & 26 & 43 & 52 & 57 & 75 & 101 & 112 & 122 & 135 & 138 & 173 \\
\hline Taiwan & 0 & 2 & 1 & 1 & 14 & 18 & 29 & 65 & 127 & 141 & 149 & 148 & 202 & 196 \\
\hline Asia index ${ }^{2}$ & 0 & 18 & 57 & 61 & 126 & 163 & 187 & 277 & 418 & 481 & 527 & 555 & 689 & 755 \\
\hline Czech Republic & 0 & 0 & 0 & 0 & 0 & 0 & 0 & 0 & 4 & 22 & 18 & 23 & 17 & 7 \\
\hline Hungary & 0 & 0 & 0 & 0 & 0 & 3 & 3 & 5 & 7 & 7 & 5 & 14 & 17 & 10 \\
\hline Poland & 0 & 0 & 0 & 0 & 0 & 2 & 3 & 3 & 9 & 9 & 13 & 9 & 12 & 11 \\
\hline Emerging Market Index ${ }^{3}$ & 1 & 27 & 70 & 78 & 159 & 267 & 306 & 416 & 596 & 676 & 743 & 804 & 1013 & 1006 \\
\hline
\end{tabular}

Notes: (1) Includes Argentina, Brazil, and Mexico.

(2) Includes Korea, Malaysia, Singapore, and Taiwan.

(3) Includes all 10 countries listed in table. 
Table 10: Financial Constraints in Other Countries and Regions

\begin{tabular}{|c|c|c|c|c|c|c|c|c|c|c|c|c|}
\hline \multirow[b]{2}{*}{ Pre-encaje $^{4}$} & \multicolumn{2}{|c|}{ Brazil } & \multicolumn{2}{|c|}{ Mexico } & \multicolumn{2}{|c|}{ Singapore } & \multicolumn{2}{|c|}{ Latin America $^{1}$} & \multicolumn{2}{|c|}{ Asia $^{2}$} & \multicolumn{2}{|c|}{ Emerging Markets $^{3}$} \\
\hline & $\begin{array}{c}\mathbf{q} \\
(1)\end{array}$ & $\begin{array}{c}\text { Euler } \\
(2)\end{array}$ & $\begin{array}{c}\mathbf{q} \\
(3)\end{array}$ & $\begin{array}{c}\text { Euler } \\
(4)\end{array}$ & $\begin{array}{c}q \\
(5)\end{array}$ & $\begin{array}{c}\text { Euler } \\
(6)\end{array}$ & $\begin{array}{c}\mathbf{q} \\
(7)\end{array}$ & $\begin{array}{c}\text { Euler } \\
(8)\end{array}$ & $\begin{array}{c}\mathbf{q} \\
(9)\end{array}$ & $\begin{array}{c}\text { Euler } \\
(10)\end{array}$ & $\begin{array}{c}\mathbf{q} \\
(11)\end{array}$ & $\begin{array}{c}\text { Euler } \\
(12)\end{array}$ \\
\hline Cash & $\begin{array}{l}-21.20 \\
(19.72)\end{array}$ & $\begin{array}{l}-4.47 \\
(5.94)\end{array}$ & $\begin{array}{l}-0.79 \\
(0.56)\end{array}$ & $\begin{array}{c}-0.63 * * \\
(0.31)\end{array}$ & $\begin{array}{l}0.80^{*} \\
(0.41)\end{array}$ & $\begin{array}{c}0.27 \\
(0.29)\end{array}$ & $\begin{array}{c}-1.78 * * \\
(0.66)\end{array}$ & $\begin{array}{l}-1.31 * \\
(0.69)\end{array}$ & $\begin{array}{l}1.22 * * \\
(0.61)\end{array}$ & $\begin{array}{c}0.76 \\
(0.60)\end{array}$ & $\begin{array}{l}1.22 * * \\
(0.62)\end{array}$ & $\begin{array}{c}0.77 \\
(0.60)\end{array}$ \\
\hline Cash*Size & $\begin{array}{c}21.54 \\
(18.76)\end{array}$ & $\begin{array}{c}8.58 \\
(7.88)\end{array}$ & $\begin{array}{l}0.97 * \\
(0.54)\end{array}$ & $\begin{array}{l}0.58 * \\
(0.33)\end{array}$ & $\begin{array}{c}1.29 \\
(1.01)\end{array}$ & $\begin{array}{c}0.90 \\
(0.92)\end{array}$ & $\begin{array}{c}1.95^{* *} \\
(0.67)\end{array}$ & $\begin{array}{l}1.34 * \\
(0.71)\end{array}$ & $\begin{array}{c}0.95 \\
(0.83)\end{array}$ & $\begin{array}{c}0.90 \\
(0.96)\end{array}$ & $\begin{array}{c}0.85 \\
(0.87)\end{array}$ & $\begin{array}{c}0.85 \\
(0.92)\end{array}$ \\
\hline \# obs. & 62 & 64 & 83 & 90 & 141 & 159 & 159 & 174 & 382 & 423 & 545 & 602 \\
\hline \multicolumn{13}{|l|}{ Encaje } \\
\hline Cash & $\begin{array}{l}-0.28 \\
(0.27)\end{array}$ & $\begin{array}{c}0.01 \\
(0.32)\end{array}$ & $\begin{array}{c}0.03 \\
(0.17)\end{array}$ & $\begin{array}{l}-0.02 \\
(0.04)\end{array}$ & $\begin{array}{l}1.38^{*} \\
(0.77)\end{array}$ & $\begin{array}{c}0.85 \\
(0.68)\end{array}$ & $\begin{array}{l}-0.19 \\
(0.26)\end{array}$ & $\begin{array}{l}-0.05 \\
(0.07)\end{array}$ & $\begin{array}{c}0.60 \\
(0.46)\end{array}$ & $\begin{array}{c}0.35 \\
(0.35)\end{array}$ & $\begin{array}{c}0.61 \\
(0.46)\end{array}$ & $\begin{array}{c}0.37 \\
(0.36)\end{array}$ \\
\hline Cash $^{*}$ Size & $\begin{array}{c}0.41 \\
(0.27)\end{array}$ & $\begin{array}{l}-0.00 \\
(0.34)\end{array}$ & $\begin{array}{c}0.25 \\
(0.19)\end{array}$ & $\begin{array}{c}0.09 \\
(0.12)\end{array}$ & $\begin{array}{c}0.32 \\
(0.68)\end{array}$ & $\begin{array}{c}0.53 \\
(0.59)\end{array}$ & $\begin{array}{c}0.44 \\
(0.29)\end{array}$ & $\begin{array}{c}0.13 \\
(0.10)\end{array}$ & $\begin{array}{l}-0.08 \\
(0.41)\end{array}$ & $\begin{array}{l}-0.36 \\
(0.35)\end{array}$ & $\begin{array}{l}-0.06 \\
(0.39)\end{array}$ & $\begin{array}{l}-0.38 \\
(0.36)\end{array}$ \\
\hline \# obs. & 255 & 263 & 184 & 200 & 327 & 356 & 492 & 525 & 1133 & 1221 & 1651 & 1777 \\
\hline \multicolumn{13}{|l|}{ Post-encaje } \\
\hline Cash & $\begin{array}{c}0.16 \\
(0.11)\end{array}$ & $\begin{array}{l}-0.15 \\
(0.13)\end{array}$ & $\begin{array}{c}0.05 \\
(0.15)\end{array}$ & $\begin{array}{c}0.15 \\
(0.11)\end{array}$ & $\begin{array}{c}0.79 * * \\
(0.38)\end{array}$ & $\begin{array}{c}0.76^{* *} \\
(0.36)\end{array}$ & $\begin{array}{c}0.19 \\
(0.12)\end{array}$ & $\begin{array}{l}-0.13 \\
(0.10)\end{array}$ & $\begin{array}{l}0.47^{*} \\
(0.26)\end{array}$ & $\begin{array}{c}0.06 \\
(0.13)\end{array}$ & $\begin{array}{c}0.46^{* *} \\
(0.23)\end{array}$ & $\begin{array}{c}0.04 \\
(0.13)\end{array}$ \\
\hline Cash $^{*}$ Size & $\begin{array}{l}0.76^{*} \\
(0.39)\end{array}$ & $\begin{array}{c}0.75 * * \\
(0.35)\end{array}$ & $\begin{array}{c}0.07 \\
(0.16)\end{array}$ & $\begin{array}{l}-0.17 \\
(0.11)\end{array}$ & $\begin{array}{c}-0.66 * * \\
(0.34)\end{array}$ & $\begin{array}{c}-0.70 * * \\
(0.34)\end{array}$ & $\begin{array}{l}0.71 * \\
(0.37)\end{array}$ & $\begin{array}{c}0.71 * * \\
(0.31)\end{array}$ & $\begin{array}{l}-0.39 \\
(0.25)\end{array}$ & $\begin{array}{c}0.01 \\
(0.12)\end{array}$ & $\begin{array}{c}-0.33 \\
(0.23)\end{array}$ & $\begin{array}{c}0.06 \\
(0.13)\end{array}$ \\
\hline \#obs. & 379 & 390 & 196 & 204 & 469 & 492 & 651 & 671 & 1984 & 2084 & 2721 & 2862 \\
\hline
\end{tabular}

Notes: Estimates are the coefficients on the financial constraints variable (Cash) and interaction term between Cash and Size (with Size measured as a dummy variable equal to 1 for large firms). The "q" estimates are of equation (9) and "Euler" estimates are of equation (16). Standard errors are in parentheses. * and ** denotes significance at the $10 \%$ and $5 \%$ level, respectively.

(1) Includes Argentina, Brazil, and Mexico.

(2) Includes Korea, Malaysia, Singapore, and Taiwan.

(3) Includes Argentina, Brazil, Czech Republic, Hungary, Korea, Malaysia, Mexico, Poland, Singapore, and Taiwan.

(4) The pre-encaje period is extended to 1993 (or in some cases 1994) in order to have sufficient observations for meaningful estimation. 


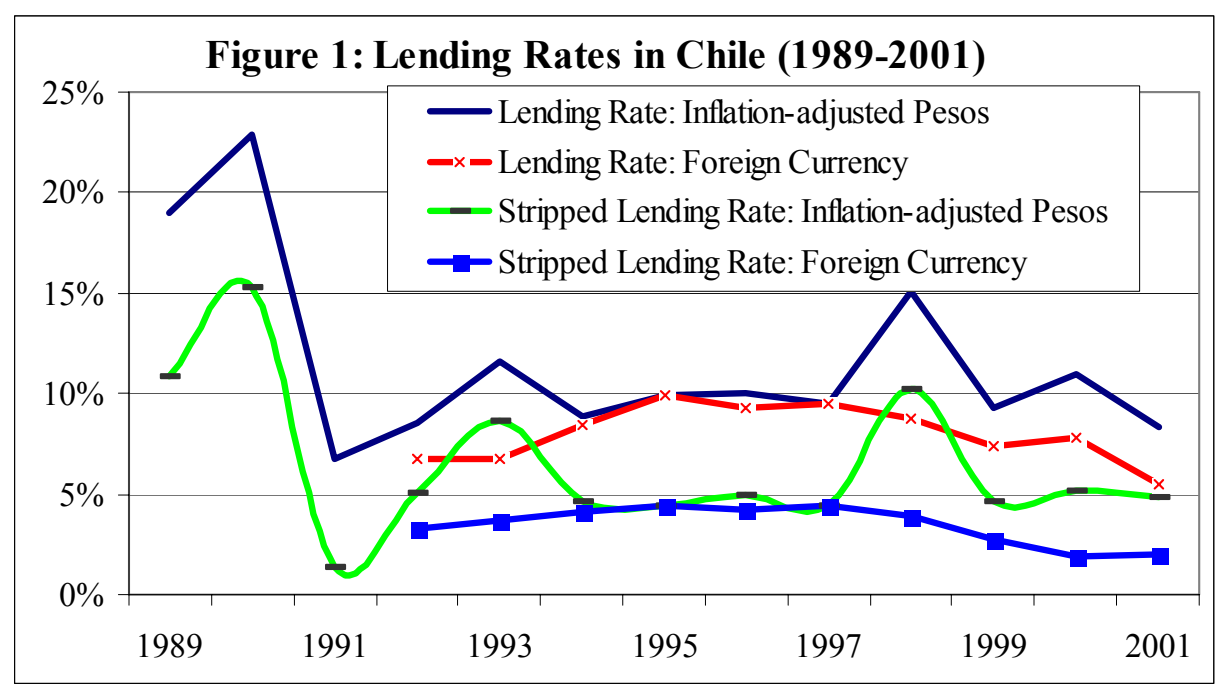

Notes: Stripped lending rates are Chilean lending rates less U.S. T-bill rate. Data from IFS (2002).
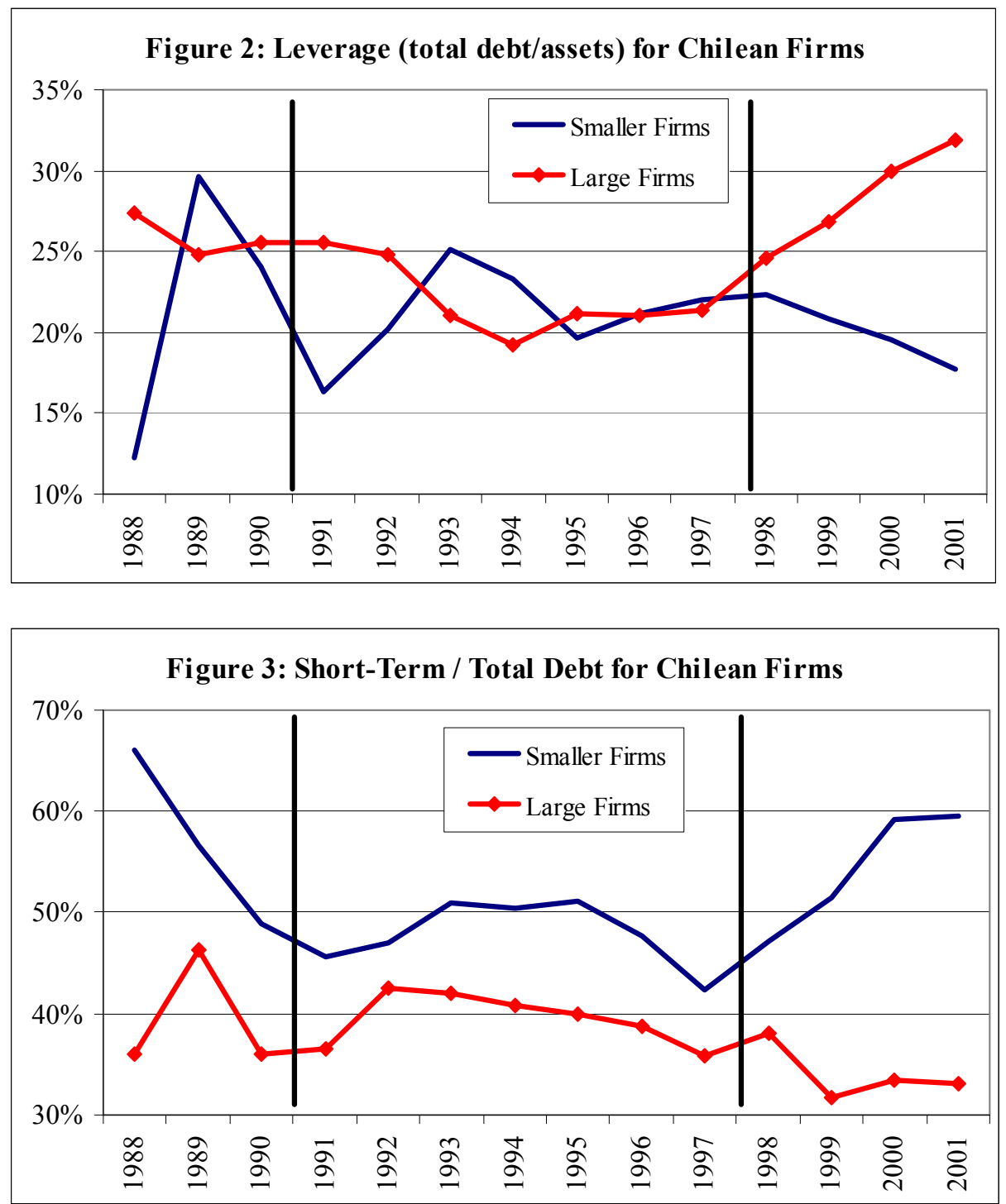

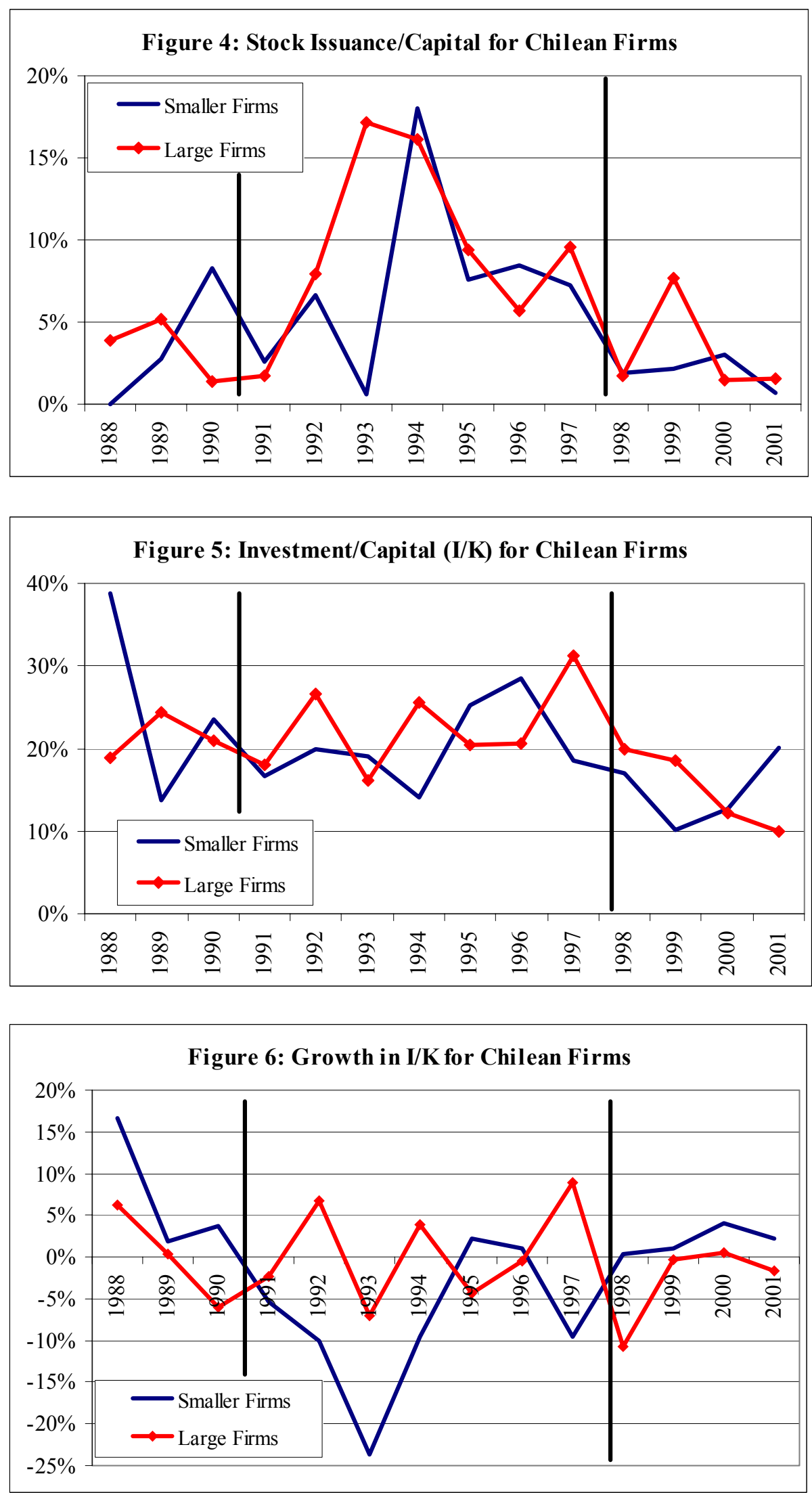